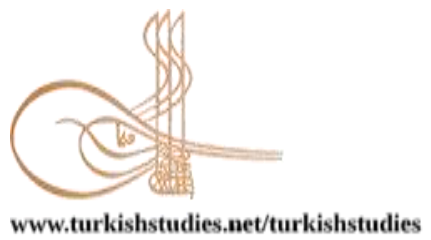

Turkish Studies

\title{
Türk Sosyolojisinde Değişen Eğilimleri Anlama Denemesi: Sosyoloji Dergisi Örneği
}

\author{
An Attempt to Understand the Changing Trends in Turkish Sociology: The Case of Journal of \\ Sociology
}

Nazife Gürhan* - İbrahim Yücedağ $\breve{~}^{* *}$

\begin{abstract}
Emerged in order to find solutions for social problems of the Western societies in the 19th century, the science of sociology gained a presence at university level in Turkey in the early 20th century. The first department of sociology that was founded in İstanbul University in 1914 has graduated students from the department and also made an important contribution to the academic publishing community by publishing a journal called Journal of Sociology. Theoretical subjects were covered more in the initial issues of this journal in order to make sure that the sociology is recognized in a theoretical way, however, in the following issues, field studies that are related to the transformation of country have been dealt with by means of exemplary cases such as modernization, rural depopulation, village monographs and the impact of mechanization on village. In this study, the researchers will attempt to understand the change in the fields of interest of and transformation of discussion topics in sociology in Turkey based on the articles published in the İstanbul University Journal of Sociology 65 issues published from 1917 to the first issue of 2019 were subjected to document and content analysis and it was aimed to find out the change in the fields of interest of our sociology based on the journal. The influence of certain people can be clearly observed from time to time in the publishing strategies of the journal. It can be observed in the journal that a sociological information production was performed within the framework of significant changes and problems that occur in the world and Turkey. It was observed that the journal included articles in a case subject in 2004 and afterward. As a result, the journal functioned as a significant production center for sociological information in Turkey from day one.
\end{abstract}

Structured Abstract: Sociology which emerged as a science in the 19th century in the world gave its initial examples in Turkey within the İstanbul University. Considering that the first sociology articles were published in journals, it can be stated that İstanbul University Journal of Sociology, which is the oldest and most fundamental sociology journal, presents a significant opportunity in terms of monitoring the development and disposition of sociology in Turkey. The subject of the present study is to reveal a portrait of the sociological disposition of the Istanbul University Journal of Sociology, from which the first sociology articles were published in connection with Istanbul University where the first sociology department was opened in our country. Accordingly, an overall analysis was made by examining the background of the change in the

\footnotetext{
* Dr. Öğr. Üyesi, Mardin Artuklu Üniversitesi, Edebiyat Fakültesi, Sosyoloji Bölümü Asst. Prof. Dr., Mardin Artuklu University Faculty of Literature, Department of Sociology. ORCID 0000-0001-7590-0095

ngurhan71@gmail.com

*** Doç. Dr. Mardin Artuklu Üniversitesi, Edebiyat Fakültesi, Sosyoloji Bölümü

Assoc. Prof. Dr., Mardin Artuklu University Faculty of Literature, Department of Sociology. ORCID 0000-0002-4698-9999

ibrahimyucedag@artuklu.edu.tr

Cite as/ Atıf: Gürhan, N. \& Yücedağ İ. (2020). Türk sosyolojisinde değişen eğilimleri anlama denemesi: Sosyoloji

Dergisi örneği. Turkish Studies, 15(5), 2421-2448. https://dx.doi.org/10.7827/TurkishStudies.42845

Received/Geliş: 11 April/Nisan 2020

Accepted/Kabul: 25 August/Ağustos 2020

Checked by plagiarism software

Copyright $($ C) MDE, Turkey 
sociological disposition of all issues published from the first issue of the journal of sociology to the first issue of 2019. The present study aims to reveal the overall trend of sociological disposition in Turkey in accordance with the sociological studies published in the Journal of Sociology. For this purpose, the document review technique among the qualitative research methods was used. Additionally, certain inferences were made based on the numerical data of the articles published in the journal using the content analysis technique.

It was observed that there was an attempt to produce sociology within the framework of the search for social harmony, balance and, order discussed in the early periods of Western sociology with the emergence of the Journal of Sociology in order to produce solutions to social problems. In this context, it is possible to state that the French sociologist Emile Durkheim, who is known for her thoughts on harmony and balance, has a clear influence on the first articles of the journal. Thus, it can be stated that the concept and methodology of Durkheim, one of the first leading names in functional sociology, dominated the journal in this period.

The influence of certain people can be clearly observed from time to time in the publishing strategies of the journal. For instance, Ziya Gökalp had an obvious effect in the early period articles of the magazine and Gökalp's establishment of the sociology chair and thus undertaking the editorial journal paved the way for the production of sociological knowledge. It is known that Ziya Gökalp acted with the idea of establishing national sociology that produces solutions to the problems of the Turkish society under the name of National Sociology. Then, in the second-period articles of the magazine -as from 1941-it can be stated that the influence of Hilmi Ziya Ülken in the journal increased. In the magazine, which started to be published again in 1989 under the editorship of Baykan Sezer, Western sociology is critically approached and a local understanding of sociology is advocated. Therefore, the possibility of using and questioning the own possibilities of Turkish sociology emerged instead of using the tradition of foreign dependent and eclecticist sociology.

It can be observed in the journal that a sociological information production was performed within the framework of significant changes and problems that occur in the world and Turkey. In other words, both the debates in the world and the problems based on the social changes in Turkey are among the subjects discussed by the authors of the journal. For instance, the increase in the rural-urban migration in the 1950s, which is one of the most significant breaking points of Turkey's economic and social life, therefore, the changes and transformations that emerge with urbanization are included in the publishing of the journal along with the articles about urbanization and village monographs. The existence of articles about globalization, modernization, and poverty in the 2000s can be given as an example as well.

It was observed that the journal included articles in a case subject in 2004 and afterward. It was observed that a thematic journalism approach was implemented, sometimes by collecting the manifestos of a symposium, sometimes by compiling the works presented in a workshop, and sometimes by specifying a particular subject. These can be listed as; sociology in Turkey, Ziya Gökalp, sociology and other sciences, utopia, progression, Durkheim, a gift to Korkut Tuna, sociological education in the West, orientalism, Pierre Bourdieu, migration, hundredth anniversary of sociology in Turkey, sociology of education, sociology of aging, and sociology of music. It should be noted that a particular interest in Ziya Gökalp and Durkheim still exists within the determined themes since these themes can be observed in the different issues of the journal in different years. This situation indicates that the journal wants to keep these themes alive.

As a result, the journal functioned as a significant production center for sociological information in Turkey from day one. It is possible to state that the journal, which emerged in connection with the Department of Sociology at İstanbul University where the chair of sociology was established in Turkey, undertook a significant role in terms of revealing the development of sociological information in Turkey.

Keywords: Sociology, Journal of Sociology, İstanbul University, İstanbul School, Ankara School.

Öz: 19. yüzyılda Batılı toplumların toplumsal sorunlarına çözüm bulmak amacıyla ortaya çıkan sosyoloji bilimi, 20. yüzyılın erken döneminde Türkiye'de de kürsü düzeyinde yer edinmeye başlamıştır. 1914'te İstanbul Üniversitesi'nde kurulan ilk sosyoloji bölümü, bölüm bünyesinde bir yandan öğrenciler yetiştirmiş bir yandan da Sosyoloji Dergisi isimli bir dergi çıkararak akademik yayın dünyasına önemli bir katkı sağlamıştır. $\mathrm{Bu}$ derginin ilk sayılarında sosyolojinin kurumsal açıdan yerleşebilmesi adına daha çok teorik konular ele alınmışken sonraki dönemlerde ise ülkenin yaşadığı dönüşüm -modernleşme, köyden kente göç, küreselleşme, postmodernizm vs.- bağlamında örnek olaylarla ilgili saha çalışmalarına yer verilmiştir. Bu çalışmada da İstanbul Üniversitesi Sosyoloji Dergisi'nde yayınlanan makalelerden hareketle Türkiye'deki sosyolojinin ilgi 
alanlarında meydana gelen değişme ve tartışma konularındaki dönüşüm anlaşılmaya çalışılacaktır. 1917'den 2019 yılının ilk sayısına kadarki 65 sayı doküman ve içerik analizine tabi tutulmuş ve dergi üzerinden sosyolojimizin ilgi alanlarındaki değişimin tespiti amaçlanmıştır. Derginin yayın stratejilerinde dönem dönem bazı isimlerin açı bir şekilde etkin olduğu, dünyada ve Türkiye'de olan önemli toplumsal değişmeler ve sorunlar çerçevesinde bir sosyolojik bilgi üretimi yapıldığı görülmektedir. 2004 ve sonrasında dergi genel olarak bir dosya konusu çerçevesinde yazılara yer vermektedir. Sonuç olarak dergi kurulduğu ilk günden bugüne değin Türkiye'deki sosyolojik bilginin üretim merkezlerinden biri olarak önemli bir işlevi yerine getirmiştir.

Anahtar Kelimeler: Sosyoloji, Sosyoloji Dergisi, İstanbul Üniversitesi, İstanbul Ekolü, Ankara Ekolü.

\section{Giriş}

Batı toplumlarının 19. yüzyılda yaşadığı kentleşme, intiharlar, ekonomik krizler ve eğitim gibi sorunlara çözüm üretmek amacıyla ortaya çıkan sosyoloji, var olan toplumsal huzursuzlukları ortadan kaldırmaya çalışırken kilisenin etkisinin azaldı̆̆ı, seküler, pozitivist ve ilerlemeci yeni bir toplumsal düzenin kurulmasını amaçlamıştır. Nitekim sosyolojinin kurucu isimlerinin özellikle de Fransız geleneğinin tartışma alanı bu yeni toplumsal düzen sorunu etrafinda şekillenmiştir. Bu çerçevede düzenin nasıl sağlanacağı, makro bir perspektiften mi hareket edileceği yoksa daha mikro bir perspektif benimsenerek bireyden mi hareket edilmesi gerektiğine dair ciddi tartışmalar ortaya çıkmıştır. A. Comte, toplumsal düzene aile üzerinden ulaşmaya çalışırken Durkheim ise toplumsal düzeni sağlayacak yegâne gücün toplumsal dayanışmayı güçlendirecek bir ahlaki yapı olduğuna vurgu yapmıştır.

Özellikle modernite tartışmalarıyla daha da belirginleşen ve tüm toplumsal küreleri etkileyen değişim ve dönüşümlerin sosyolojinin tartıştığı konuları şekillendirmesine paralel olarak, ülkemizdeki sosyoloji tartışmaları veya sosyolojik ilgi de küresel çaptaki bu değişim ve dönüşümlerden etkilenmiştir. Türk sosyolojisinin ilk dönemlerinde kıta Avrupası'nın, özellikle de Fransız sosyolojisinin önemli isimlerinden A. Comte ve E. Durkheim'ın etkisi yoğun bir şekilde hissedilmiştir. Ziya Gökalp'in Durkheim çizgisinde daha toplumcu, Prens Sabahattin'in ise Le Play ekolü bağlamında bireyci ve adem-i merkeziyetçilik çerçevesinde çalışmalar yaptığı bilinmektedir. Fransız sosyolojisinin Türkiye'nin içinde bulunduğu ve aynı zamanda tüm dünyayı etkileyen küresel çaptaki savaşlar, ekonomik krizler ve egemenlik ilişkilerindeki değişim ve dönüşümlerin yorumlanmasında ciddi etkileri olduğu hatırda tutulmalıdır.

Türkiye'de günümüze aktarılan sosyoloji yazılarının dergiler aracılığıyla kaleme alındığı düşünüldügünde yayın anlamında sosyolojiyle ilk karşılaştığımız tarih aralığg 1908-1911 yıllarıdır. $\mathrm{Bu}$ yıllar arasında sosyoloji teriminin kullanıldığ 1 ilk dergi, Cavid Bey'in çıkarmış olduğu "Ulum-i İktisadiyye" ve "İçtimaiyye Mecmuası"dır. Liberal fikir akımından etkilenen Cavid Bey'le beraber dergide Ahmet Şuayp, Mehmet Cavit ve Rıza Tevfik (Bölükbaşı) gibi önemli isimlere rastlanmış ve dergi 6 cilt ve 27 sayı yayınlanmıştır (Şahin, 2017: 10). Ulum-i İktisadiyye ve İçtimaiyye Mecmuası'nın ardından yayın hayatına başlayan dergi ise İstanbul Üniversitesi Sosyoloji Dergisi'dir. $\mathrm{Bu}$ dergi uzun yıllar inişli çıkışlı bir yayın hayatı yaşamış, bazı yıllar yayınlanamamıştır. Ancak tüm olumsuzluklara rağmen derginin Türkiye'deki sosyoloji anlayışındaki değişimi yansıtma gücüne sahip olduğu belirtilmelidir. Dolayısıyla, Sosyoloji Dergisi'nin, Türkiye'de sosyolojinin gelişme özelliklerini ve eğilimlerini izlemek açısından önemli bir imkân sunduğu düşünülmektedir. Bu çalışmanın konusu ülkemizin en köklü üniversitesi olan İstanbul Üniversitesi'ne bağlı olarak sosyoloji yazılarının yayınlandığı İstanbul Üniversitesi Sosyoloji Dergisi’nin başlangıçtan günümüze kadar olan sosyolojik temayülünün bir portresini ortaya çıkarmaktır. Bu amaçla sosyoloji dergisinin ilk sayısının yayınlandığı 1917'den 2019 yılının ilk sayısına kadar yayınlanan bütün sayıların sosyolojik temayüldeki değişiminin arka planı irdelenerek genel bir analizi yapılmıştır. 


\section{Metodoloji}

Bu çalışmada, nitel araştırma yöntemlerinden doküman incelemesi tekniği kullanılmıştır. Bilindiği gibi doküman incelemesi, nitel araştırmalarda araştırılan probleme ilişkin yazılı materyallerin çözümlenmesidir. Gözlem ve görüşmenin mümkün olmadığı araştırmalarda tek başına veri toplamak amacıyla araştırmanın geçerliliğini artırmak için kullanılan bir tekniktir (Yıldırım ve Şimşek, 2005: 188-189). Yazılı ve görsel dokümanların incelenmesi araştırmada daha zengin ve kapsamlı bir çıkarım sağlanmasına ve araştırma konusunun geçmişine ya da tarihsel sürecine 1 şı tutmasına yardımcı olmaktadır. Doküman incelemesinde yazılı ve görsel materyallere ek olarak bilgisayar veya internet kullanılarak elektronik bir ortam ve formatta da veriler elde edilebilmektedir (Akturan, 2008: 117-119). Araştırmanın veri grubunu sosyoloji dergisinin ilk yayın hayatına başladığı yıl olan 1917 yılından başlayarak 2019 yılının ilk sayısına kadar dergide yayınlanmış bütün sayılar oluşturmaktadır. Bahsi geçen sayılara İstanbul Üniversitesi Sosyoloji Dergisi'nin kendi web sayfasının arşiv bölümünden erişilmiştir. Bu kapsamda dergide yayınlanan toplam 65 sayı incelenmiştir. Dergide 656 makale ve 135 kitap değerlendirmesi mevcuttur. Ayrıca az da olsa kongre ve semopzyum değerlendirmelerine de yer verildiği görülmüştür.

Çalışmada kullanılan bir diğer teknik de içerik analizidir. İçerik analizi, yazılı belgeler veya diğer iletişim ortamlarında yer alan bilgi ve sembolleri, başka bir deyişle içeriği inceleme tekniğidir (Neuman, 2012: 67). İncelenen dokümandaki ifadelerin belirli özelliklerini sistematik ve nicel bir yolla tanımlama, nitelendirme ve metne ilişkin bazı çıkarımlarda bulunma çabasıdır. İçerik analizinde veriler, belli kategoriler çerçevesinde bir araya getirilerek yorumlanmakta; ön plana çikan temalar üzerinden analizler yapılabilmektedir. $\mathrm{Bu}$ nedenle de tematik analiz olarak da adlandırılabilmektedir (Bal, 2016: 255). Bu bağlamda çalışmada içerik analizi tekniğiyle dergide yayınlanan makalelerin sayısal verilerinden hareketle bazı çıkarımlarda bulunulmaya çalışılmıştır. Başka bir ifadeyle dergide yayınlanan makalelerin tema sıklıkları tespit edilerek dönemsel olarak temalardaki farklılaşmalardan hareketle derginin sosyolojik eğilimindeki değişim ve dönüşüm üzerine bazı tespitler elde edilmeye çalışılmıştır.

\section{Kuruluş Yılları: Gökalp-Durkheim Etkisi}

Türkiye'de ilk sosyoloji dersinin 1911'de Selanik'teki İttihat ve Terakki İdadisi'nde Ziya Gökalp tarafindan verildiği bilinmektedir. Bunun öncesinde ise İstanbul Üniversitesi Edebiyat Fakültesi'nde Ahmet Şuayb tarafindan 1910 yılında yine sosyoloji dersleri verilmiştir. Nilgün Çelebi, Ziya Gökalp'in İ.Ü. Edebiyat Fakültesi'nde 1914'te sosyoloji dersini verdiğini belirtse de, Türkiye'de sosyolojinin kurumsallaşması yönünde atılan ilk adımın tarihinin 1915 olduğunu vurgular (Çelebi, 2004: 20). H. Bayram Kaçmazoğlu da sosyolojinin kurumsallaşmasının esasında Gökalp'in dersleriyle sağlandığını ve tarih olarak da 1914 olduğunu belirtir (Kaçmazoğlu, 2002: 46).

Ziya Gökalp'in Türk sosyolojisinin kurumsallaşmasında ve şekillenmesinde asli bir yere sahip olduğunu söyleyebiliriz. Nitekim ülkemizde ilk sosyoloji dergisi ilk ismiyle Iç̧timaiyat Mecmuası şimdiki adıyla İstanbul Üniversitesi Sosyoloji Dergisi Ziya Gökalp tarafından 1917 yılında yayın hayatına başlamıştır. Dergi ilk yıl altı sayı çıkarmış olmasına rağmen yayın sürecine her y1l düzenli bir periyotta devam edememiştir. 1941, 1943, 1945, 1947, 1952, 1953, 1954, 1955, 1957, 1958, 1960, 1961, 1962, 1964, 1967, 1989, 1991, 1992, 1995, 1999, 2003 ve 2003'ten itibaren günümüze kadar düzenli bir şekilde yılda iki kez dergi sayılarını çıkarmaktadır.

Derginin ilk sayılarının temel sorunsalı yeni ortaya çıkan bir bilimin neliği ve nasıl bir yöntem izleneceğidir. Bu bağlamda Türkiye'de yeni kurumsallaşan bir bilim olan sosyolojinin sınırlarını çizmek ve nasıl bir yöntem izleneceğini ortaya koymak ana tema olarak karşımıza çımmaktadır. Sosyolojinin kurucu isimlerinden Durkheim'ın ilk çalışmalarının sosyolojinin felsefeden ve psikolojiden ayrı bir bilim dalı olduğunu göstermeye ve sosyolojiye özgü bir konu ve yöntem belirlemeye çalıştı̆̆ gibi Sosyoloji Dergisi'nin ilk çalışma konularının da bu yönde şekillendiği görülmektedir (Tatlıcan ve Balkız, 2017: 13-67). Örneğin Ziya Gökalp'in “İçtimaiyat 
ve Fikriyat” ve Necmettin Sadak'ın “İçtimaiyat Nedir?” ve "İçtimaiyyat Bir İlim midir?” makaleleri sosyolojinin ne olduğu sorunsalı üzerine odaklanırken; Ahmed Emin Yalman'ın "İçtimaiyatta İhsai Usul" ve yine Ziya Gökalp'in "Milli İçtimaiyat: Usul" makaleleri de sosyolojinin yönteminin nasıl olması gerektiği üzerine yapılan tartışmaları içermektedir.

İçtimaiyat Mecmuasının ilk dönem sayılarında genel sosyoloji ve metodoloji, sosyoloji tarihi, ahlak sosyolojisi, eğitim sosyolojisi, aile sosyolojisi, toplum tarihi ve milli sosyoloji konularında yazılar yayınlanmıştır (Ercan, 2013: 18). Derginin ilk sayılarında Fransız Sosyolojisi ve özelde de Emile Durkheim'in etkisi açıkça hissedilmektedir. Bu dönemde Durkheim sosyolojisinin kavram ve metodolojisinin dergiye hâkim olduğu görülmekte; hatta Durkheim sosyolojisinin ana teması olan toplumsal sistemdeki dengeyi sağlamaya çalışma, düzen ve uyuma vurgu yapma derginin ilk sayısının "Mukaddime"sinde (giriş) de göze çarpmaktadır. Memleketin geçirdiği toplumsal buhran sonucunda toplumsal kurumlardaki çözülmenin ve tekrar düzenlemenin gerekli olduğu belirtilerek toplumda hâkim olan kanunları bilmenin toplumun ıslahı açısından gerekli olduğu ifade edilmektedir (1917:2). Bu dönemde Gökalp ve öğrencileri -örneğin Necmettin Sadak- Türkiye'ye idea-yönelimli ve polity-temelli bir sosyoloji yerleştirmiş ve Çelebi'ye göre bu çizgi sonraları "Durkheim sosyolojisi" olarak adlandırılsa da, "Gökalp'in yorumundan geçmiş bir "Durkheim" veya Türkleşmiş bir Durkheim çizgisi”" olarak adlandırmak daha doğru gibi görünmektedir" (Çelebi, 2004: 21).

İlk dönemlerde hemen her sayıda Durkheim'in bir makalesi çeviri olarak yayınlanmaktadır. 1917 yılında yayınlanan 26 makalenin 8'i Durkheim'e aittir. Örneğin ilk dört sayıda yayınlanan Durkheim'in (1917) "Fucürün Nehyi ve Menşeleri-I-II-III-IV" adlı makaleleri egzogami ve endogami kavramlarından hareketle modern ailenin ilk biçimlerinin bu toplumlarda nasıl vücut bulduğu ve evlilik biçimlerinin hangi unsurlara göre şekillendiği üzerine yazılmış çalışmalardır. Yine Emile Durkheim'in 4-5 ve 6. sayılarda "On Dokuzuncu Asırda Fransa'da İçtimaiyyat I-II- İkinci Devre" adlı çalı̧̧maları yer almaktadır. Bu çalışmalarda sosyolojinin Fransa'da nasıl geliştĭgi ve hangi evreleri geçirdiği anlatılmaktadır.

Bu şekliyle Batı'dan aktarılan ilk bilgilerle şekillenen sosyolojinin dışa bağımlı ve aktarmacı karakterine karşılık yine ilk dönem sosyologları Türk toplumunun kendi sorunları üzerinde de düşünerek açıklama ve çözüm önerileri sunmuşlardır (Ercan, 2013: 5). Bu durum İçtimaiyat Mecmuası'nın ilk sayısının Mukaddimesinde de (1917: 3) açıkça belirtilmektedir. Mecmuanın konu itibariyle sosyolojiyle alakalı yayınları ihtiva edeceği ve bu yazıların da nazari (teorik), ameli (pratik) olmak üzere iki kısımdan oluşacağı ifade edilmiştir. Nazari kısımda usul, dini, ahlaki, edebi, iktisadi içtimaiyat meseleleri tartışlırken ameli yani pratik kısımda ise bu teorik bilgilerin ülkemize uygulanması neticesinde çıkan sonuçların ele alınacağı belirtilmiştir. Ayrıca ülkenin toplumsal bir kriz sürecinden geçtĭgi ve bu krize de ancak sosyoloji aracılığıyla çözüm üretilebileceği belirtilmektedir.

\section{0-1950 Arası: Gökalp’ten Ülken'e}

Gökalp'in 1919 yılında Malta'ya sürülmesiyle hem bölüm hem de derginin faaliyetleri 1941 yılına kadar kesintiye uğramıştır.1941 yılına gelindiğinde ilk sayılarda İçtimaiyat olarak isimlendirilen bilim ve dergi adının artık sosyoloji olarak kullanılmaya başlandığını görüyoruz. Örneğin Hilmi Ziya Ülken'in "Sosyolojinin Mevzuu ve Usulü”, Ziyaeddin Fahri Findıkoğlu'nun "Neo Pozitivizme Göre Sosyolojik İlliyet”, Lütfi Erişçi'nin “Türkiye'de Sosyolojinin Tarihçesi ve Bibliyografyası" ve Robert Ezra Park-Ernest Burgess'ten çevrilen "Sosyolojiye Giriş" makaleleri bu bağlamda değerlendirilebilir.

1941 'den itibaren dergide açıkça Hilmi Ziya Ülken'in etkisi görülmektedir. Burada şunu da belirtmek gerekmektedir ki İstanbul Ekolü ve Ankara Ekolü olarak iki kampa ayrılan Türk sosyologlarının ilgi alanları ve izledikleri yöntem de ülkemiz sosyolojisi açısından farklılık göstermektedir. Nitekim Hilmi Ziya Ülken, Ziyaeddin Fahri Fındıkoğlu ve Nurettin Şazi 
Kösemihal'in oluşturdukları grup İstanbul Ekolü, Niyazi Berkes, Behice Boran ve Mediha Berkes'in oluşturdukları grup da Ankara Ekolü olarak tanımlanmaktadır (Kaçmazoğlu, 2002: 46-93). Ankara Ekolü, evrenselliği ve Batılılaşmayı önemsemiş ve “Batı'nın gelişmesine kaynaklık eden evrensellik, hümanizma, Latin kültürü, eski Yunan medeniyeti gibi tek taraflı konuları, evrensel kaynaklar olarak sunmuştur" (Kaçmazoğlu, 2002: 48). Ekonomi, köy ve şehir sosyolojileri esas olarak üzerinde durdukları konular arasındadır. Bu dönemde Niyazi Berkes'in (1942) "Bazı Ankara Köyleri Üzerine Bir Araştırma'sı, "Köy Nüfusu” (1941) ve "Köy Şekilleri”" (1941) makaleleri köy çalışmalarına birkaç örnek olarak verilebilir. Aynı şekilde Behice Boran'ın 1942'de yayınlanan "Köyde Sosyal Tabakalaşma" makalesi de köy çalışmalarına örnek verilebilecek eserlerdendir. Bunun yanında Ístanbul Ekolü ise, Fransız düşün kaynaklarından beslenmiş ve felsefe ağırlıklı bir ekoldür. Gelenekçi sosyolojimizden özellikler taşısa da bu ekol, kendi içinde homojen bir yapı sergilemekten uzaktır. Örneğin, “H. Z. Ülken eklektik eğilimler taşırken, bu dönemde Marksizm’i de hatırlatmadan geçemez. Fındıkoğlu'na gelince, o da eklektik, fakat Alman sosyolojisinden kaynaklanan 'sosyal siyaset' anlayışını ülkemize yerleştirme çabasındadır. Kösemihal, Le Play'in devamcılarınca geliştirilen tecrübi sosyoloji anlayışının üniversitedeki temsilcisi izlenimini verir" (Kaçmazoğlu, 2002: 57). Özellikle Ülken'in tartıştığı konular genellikle Durkheim ve Gökalp etkisinde gelişmiş, Gökalp'in çalıştı̆̆ birçok konu Ülken tarafından da ele alınmıştır. Özellikle Cumhuriyet döneminin önemli düşünürlerinden olan Ülken'in milliyetçilik konusunda söyledikleri önemli yer tutmuş ve adeta devletin resmi düşünürü haline gelmiştir. Ekol, Batı medeniyetine önem vermiş, din ve sanat sosyolojilerine ilgi duymuş, ekonomi, metafizik, Marksizm ve aile sosyolojisi gibi konulara da eğilmiştir. Ancak bu dönemde yoğun bir şekilde Ülken'in etkisini görmek mümkündür. Türkiye'de Çağdaş Düşünce Tarihi (2005), İslam Felsefesi Kaynaklarl ve Etkileri: Eski Yunandan Çağdaş Düşünceye Doğru (1998), Türk Tefekkürü Tarihi (2004) gibi çalışmaları Türk düşün dünyasına yaptığı önemli katkılardan birkaç tanesidir. Ercan (2013: 62) da benzer şekilde 1940-1960 arasında Türkiye'de sosyoloji faaliyetlerine damgasını vuran hatta bu yıllarda kürsünün tek hâkiminin Hilmi Ziya Ülken olduğunu belirtmektedir. Gerek dergi editörlüğü gerek makaleleri gerekse de kitap değerlendirmeleriyle Hilmi Ziya Ülken derginin en çok göze çarpan yazarlarındandır. 1941 ve 1958 yılları arasında 23 makalesi 80 kitap değerlendirmesi bulunmaktadır. Özellikle 1947 yılında yayınlanan Cilt 2 Say1 4-5'de 4 makalesi ve 38 kitap değerlendirmesiyle Ülken, derginin o dönemki sayısına damgasını vurmaktadır. Yine 1952 yılında Cilt 2 Sayı 7'de 8 makalenin 3'ü ve 18 kitap değerlendirmesi Hilmi Ziya Ülken'e aittir. Dikkat çekici bir başka özellik de kitap değerlendirmelerinin İngilizce ve Fransızca dilindeki kitaplar olmasıdır. Bu durum Ülken'in bu dönemde sosyolojiye temel olacak bazı kaynakları Türkçe'ye kazandırma çabası olarak görülebilir. Ayrıca dergide yoğun bir şekilde yapılan kitap değerlendirmeleri sosyoloji literatürünün tanıtılmasında önemli rol oynamıştır.

Bilindiği üzere Türkiye'de Ankara Üniversitesi Dil Tarih ve Coğrafya Fakültesi bünyesinde 1941 yılında eğitime başlayan Ankara ekolü olarak da adlandırılan sosyoloji kürsüsü İstanbul ekolünden farklı olarak Amerikan sosyolojisinin etkisi altındadır. Ankara ekolünün önemli isimlerinden olan Behice Boran ve Niyazi Berkes sosyoloji eğitimlerinin bir kısmını Amerika Birleşik Devletleri'nde yaparak Türkiye'ye dönmüşlerdir. Anadolu köylerinde araştırmalar yaparak Türk toplumunun özellikle köy ve kent yapısını ortaya koymaya çalışmışlardır (Çelebi, 2010: 60). $\mathrm{Bu}$ dönemde ülkedeki genel sosyolojik temayülün İstanbul Üniversitesi sosyoloji dergisinde de yansımalarını bulduğunu söyleyebiliriz. Nitekim bu yıllarda dergide Amerikan sosyolojisinin önemli isimlerinden ve Chicago okulunun temsilcilerinden Robert Ezra Park ve Ernest Burgess'in yazılarına rastlyyoruz. Robert Ezra Park- Ernest Burgess- "Sosyolojiye Giriş" ve "Tecerrüd" makaleleri bu sayıda yer almıştır. Buradan hareketle Park ve Burgess'ın Amerikan Sosyolojisi'nde özellikle kent araştırmalarında önemli bir yere sahip olduğu düşünüldüğünde derginin çoğunlukla Fransız sosyolojisinin etkisi altında kalmasına rağmen diğer sosyolojik gelenekleri de takip ettiği söylenebilir. (Ercan, 2013: 63). 
Bu dönemde Türkiye'de sosyolojinin gelişmesine ve kurumsallaşmasına etki eden diğer bir gelişme de Almanya'da yaşanan olaylar nedeniyle 1933'ten sonra Alman akademisyenlerin Türkiye'ye gelişidir. 1936'da Alman profesörlerden sosyoloji ve ekonomi kökenli olanlar İstanbul Üniversitesi İktisat Fakültesi'ne geçmişlerdir. Kessler, Meumark, Ropke, Rustow ve Issac, İ.Ü. İktisat Fakültesi içinde Weber çizgisinde ve tarih-kültür temelli bir sosyoloji dersi vermeye başlamışlardır. Kessler'in İstanbul Üniversitesi Edebiyat Fakültesi Sosyoloji Kürsüsü'ne getirdiği yenilikleri Z. F. Fındıkoğlu şöyle belirtmektedir:

“Prof. Dr. Kessler'in 1933-1934'te Türkiye'de başlayan sosyoloji öğretmenliği memleketimizde o zamana kadar yapılan sosyoloji öğretimine birçok yenilikler getirdi. Ortada "klan, totem, mana, social conscience" gibi kelime ve terimler ile dolu bir Durkheim cereyanı vardı ki Gökalp’ten başka hiç kimse anlamını anlamamış, pratiğini yapmamıştı. Gökalp ise 1924'te ölmüştü... Prof. Kessler'in öğretimi herkese yabancı geliyordu. Her şeyden evvel, bu öğretim, iradeci ve aklın tesirine inanan bir sosyoloji anlayışına dayanıyordu.....teorik değil, pratik gayeler güdüyordu." (Fındıkoğlu'ndan akt; Çelebi, 2010: 58).

Kessler'in sosyoloji anlayışı, sosyolojiyi doğal bir bilim olarak gören Fransız pozitivist sosyoloji geleneğinden uzak Alman Tarih Okulunun ve özellikle de Weber'in etkisiyle sosyolojiyi bir kültür bilimi olarak gören geleneğe yakındır (Çelebi ve Kızılçelik, 2008: 392-393). Kendisini teorisyen olarak kabul etmeyen ve sosyoloji alanında belirli bir teori üretmeyen Kessler'in sosyolojiye yaptığı katkılar daha çok sosyal politika programlarının geliştirilmesi yönündedir. Kessler'in, daha önceleri Fransız Sosyolojisi'nden (Durkheim Ekolü) etkilenmiş olan Türk sosyolojisine en önemli katkısı ise Max Weber ve özellikle de Ferdinand Tönnies gibi Alman sosyologlara kapıları açmasıdır (Kadıŏglu ve Erginöz, 2009: 448). Kessler'in bahsedilen bu etkilerine rağmen İstanbul Üniversitesi Sosyoloji dergisinde yer bulamaması çok ilginçtir. Bu konudaki tek istisna 1941 yılında Cilt 2 Sayı 1'de Hilmi Ziya Ülken tarafından yapılan "İçtimaiyata Başlangıç" kitabının değerlendirmesidir. Onun dışında herhangi bir makalesi veya kitap değerlendirmesi bulunmamaktadır.

$\mathrm{Bu}$ sosyoloji öğretimi bir yandan Prens Sabahattin'in çizgisini andıran socius temelli bir sosyoloji ile ortak özellikler göstermekte bir yandan da Türkiye için çok yeni olan toplum-merkezli ve politika yönelimli bir sosyoloji anlayışının ilk örneklerini sunmaktadır. Sonrasında, toplummerkezli, politika-yönelimli, alan araştırması verisine dayalı sosyolojinin tipik temsilcisi ise Ziyaeddin Fahri Fındıkoğlu'dur (Çelebi, 2004: 23). Burada Prens Sabahattin'e de değinmek gerekmektedir. Prens Sabahattin, Türk sosyoloji tarihinde Ziya Gökalp'in gölgesinde kalmış bir düşünürdür. Ziya Gökalp'in milliyetçi ve toplumcu aynı zamanda da Durkheim'cı bakış açısına karşı Prens Sabahattin ise Le Play okulunun etkisinde, monografiyi önemseyen, adem-i merkeziyetçi ve bireyci bir sosyolojinin temsilciliğini yapmıştır. Toplumcu yapıya karşı bireyci yapının Osmanlı Devleti'ni kurtaracağını ileri süren Prens Sabahattin'in 1918'de basılan “Türkiye Nasıl Kurtarılabilir?" (1999) isimli eseri Osmanlı Devleti'nin içinde bulunduğu buhrandan kurtuluş reçetesi olarak ortaya koyduğu bir çalışmadır. Prens Sabahattin'e göre bireycilik, şahsi teşebbüsü güçlendirecek ve bu sayede adem-i merkeziyetçi bir yapının da kurulmasını sağlayacaktır. Ona göre adem-i merkeziyetçilikte, yönetimin bir elde toplanması bir yana bırakılmakta ve yetki daha alt ve küçük birimlere devredilmektedir.

1942-1950 yılları arasında Sosyoloji dergisinde yayınlanan makalelerin genel olarak teorik çalışmalar olduğunu vurgulayan Ercan (2013: 64), ele alınan konuların 19. yy. sosyoloji çalışmalarının devamı niteliğinde yani Fransız sosyolojisinin etkisinde olduğunu belirtmiştir. Ancak bu dönemde peşin kabullerden ziyade eleştirel bir yaklaşım gösterilmeye başlandığını da ifade etmektedir. Dergide ele alınan konular genel sosyoloji ve metodoloji, iktisat, din, hukuk, antropoloji, sosyal psikoloji, tarihsel sosyoloji, yerli ve yabanc1 sosyologlar ve Türkiye'de sosyoloji çalışmalarıdır. 


\section{0'li ve 1960'lı Yıllarda Değişme Meselesi}

Türkiye'de önemli ekonomik ve sosyal değişmelerin olduğu 1950'li yıllarda sanayileşme çabalarıyla ilişkili olarak artan kırdan kente göçle birlikte sosyolojik ilginin odağının makro sosyal teorilerden mikro sosyal teorilere doğru kaydığını söyleyebiliriz. Böylece batılılaşma önünde bir engel olarak görülen köy sosyal hayatı, dini, kültürel ve antropolojik aç1lardan ele alınarak köy çalışmalarına ağırlık verilmiştir. Özellikle de Mehmet Ali Şevki'nin Kurna Köyü Monografisi bunun ilk örneklerindendir. 1950'li yıllarda Sosyoloji Dergisinde öne çıkan konular genel sosyoloji ve metodoloji, köy sosyolojisi, sosyal ve kültürel antropoloji ve din sosyolojisidir (Ercan, 2013: 69).

Bilindiği gibi 1950’lerin sonuna kadar Türkiye'deki köy-kent dengesinin halen köy lehinde olması, ekonomik kalkınma politikalarının temelinde köylerin kalkındırılmasına merkezi bir önem atfedilmesi ve Türk modernleşmesinin köyden başlamasına dair genel kanı sosyolojide köy monografi ve incelemeleri üzerinden toplumsal yapı analizlerine ağırlık verilmesine yol açmıştır (Akyurt ve Yaman, 2012: 184). 1955 yılına gelindiğinde cilt 2 sayı 10-11'de köy monografilerinin olduğunu görüyoruz. Bunlar Turhan Yörükhan ve Turgut Cebe'nin "Çatak Köyü Araşttrması", Rahmi Taşçığlu'nun Manisa İli Mütevelli Köyü Monografisi ve Manisa İli Kayalıoğlu Köyü Monografisi, Cavit Orhan Tütengil'in “Keçiller Köyü İncelemesi”, Yusuf Kurhan'ın “Eskitaşlı Köyü Monografisi" ve "Yenidebir Köyü Monografisi" ve son olarak Hilmi Ziya Ülken ve Ayla Tanyel'in birlikte yaptıkları "Gönen Bölge Monografisi”dir.

Ankara Üniversitesi Sosyoloji bölümünün 1940'l1 yıllarda Amerikan sosyolojisinin etkisinde kalarak köy üzerinde artan saha çalışmaları kuramsal tartı̧̧malardan uzaklaşılarak mikro sosyoloji alanına genel bir eğilim oluşturmuştur. Bu eğilimin İstanbul Üniversitesi Sosyoloji dergisindeki yansımalarının ise 1950 'li yıllara tekabül ettiğini söyleyebiliriz. Gerek yukarıda bahsi geçen köy monografileriyle gerekse köy araştırmalarındaki usulün nasıl olacağına dair makalelerin yayınlanmasıyla saha çalışmalarına ilginin arttığını görüyoruz. Mümtaz Turhan'ın (1957) “Köy Tetkiklerinde Kullanılacak Metotlar Hakkında Bazı Düşünceler" makalesi buna örnek olarak verilebilir.

Burada belirtilmesi gereken bir husus da Cahit Tanyol'un köy çalışmalarındaki öncü makaleleridir. Her ne kadar 1950'li yıllarda sosyoloji dergisinde köy monografilerine genel bir eğilimin arttığı görsek de ilk çalışmaların 1947 yılında Cahit Tanyol tarafından yapıldı̆̆ını görüyoruz. Örneğin 1947 y1lında "İçtimai Monografi Hazırlıklarl: Prens Sabahaddin", 1952' de "Baraklarda Örf ve Adet Araştırmaları 1", 1953'de "Baraklarda Örf ve Adet Araştırmaları 2", 1954'de "Baraklarda Örfve Adet Araştırmaları 3" makaleleri, 1958'deki "Traktör Giren 50 Köyde Nüfus Hareketlerinin ve İçtimai Değişimlerin Kontrolü", 1961'de "Peşke Binamlısı Köyü", 1962'deki "Elifoğlu Köyü" ve "Türkiye'de Köye Yönelme Hareketleri" makaleleri köy çalışmalarında önemli yapı taşlarıdır. Tanyol, bu monografilerde köylerin geçim kaynakları, toprak dağılımı, ticaret, dini yaşam ve siyasal görüşler gibi farklı alanlarda incelemeler yapmıştır. Ayrıca traktörün köy yaşamına girmesi ile birlikte meydana gelen toplumsal değişmeyi de ele almıştır.

Türkiye'nin sanayileşme deneyiminin toplumsal yansımalarıyla ilgili dergide yok denecek kadar az çalışma mevcuttur. Bu durumun bir istisnası ise Erol Tümertekin'in (1961) "İstanbul'da Sanayi Faaliyetlerinin Bünyesi ve Türkiye Sanayiindeki Yeri" makalesidir. Bu makalede Tümertekin, İstanbul'daki işyerleri ve çalışan sayılarının, işçi ücretlerinin ve İstanbul'daki sanayi faaliyetlerinin ülke ekonomisine katkısı gibi konuları özellikle de istatistiki yöntemle anlamaya çalışmıştır. Ayrıca bu dönemde Ziyaeddin Fahri Fındıkoğlu'nun Karabük şehriyle alakalı çok sayıda makalesinin başka dergilerde yayınlanması ve Sosyoloji Dergisinin kapsamına girmemiş olması da ilginç bir durumdur. $\mathrm{Bu}$ duruma örnek olarak Fındıkoğlu'nun yine İstanbul Üniversitesi İktisat Fakültesi bünyesinde çıkan Sosyoloji Konferansları dergisinde yayınlanan "Karabük'ün Teşekkülü ve Bazı Demografik ve İktisadi Meseleler”'i (1960), “Karabük'de Sanayileşmenin İktisadi ve İctimai Tesirleri” (1961) ve 
"Beledi Hizmetler ve Amme İdaresi Bakımından Karabük" (1963) makaleleri örnek olarak verilebilir.

1964 yılının 2. cildi 19. ve 20. sayısında İstanbul Üniversitesi Sosyoloji Bölümü’nün 50. Kuruluş yıl dönümü nedeniyle Ziya Gökalp konu edilmiştir. Bu bağlamda derginin bu sayısında Ziya Gökalp'le ilgili 5 makalenin yer aldığını görüyoruz. Nurettin Şazi Kösemihal'in "Kürsümüzün 50. Yılı Münasebetiyle Ziya Gökalp”, Cahit Tanyol'un "Ziya Gökalp’in Kişiliği, Ülkücülügü̈, Bilim Adamlı̆̆g”, M. Nermi'nin "Ziya Gökalp'le Illgili Anilar", Cavit Orhan Tütengil'in "Ístanbul Üniversitesi Sosyoloji Öğretimi ve Ziya Gökalp” ve Muzaffer Sencer'in "Sosyoloji Kürsüsü'nün 50. Kuruluş Yıldönümünde Ziya Gökalp” makaleleri Ziya Gökalp'in sosyolojisini ve İstanbul Üniversitesi sosyoloji bölümüne katkılarını ele almaktadır.

1967 yılında dergide ilk kez kent sosyolojisi çalışmaları bağlamında makalelerin kaleme alındığı görülmektedir. Özellikle konut ve sınıf ilişkisi bağlamında ele alınan makalelerde kentleşmeyle birlikte artan kent nüfusunda sınıfsal ayrışmanın kentsel yaşam alanlarındaki farklılaşmaya neden olması ele alınmıştır. Bu sayıda eğitim sosyolojisi, yöntem, edebiyat sosyolojisi, mimari ve sosyoloji ilişkisi gibi alt alanlarda çalışmalar yapılmıştır. Nurettin Şazi Kösemihal'in "Toplumsal Çevre ve Konut İlişkileri", "Sosyolojide Yöntem" ve "Yurdumuzda Edebiyat Sosyolojisiyle İlgili Araştırmalar" 1 , Cemil Meriç'in “Ideoloji”"si, Sencer'in "Bir Sosyal Sinıf Kriteri Olarak Yerleşme Kesimi ve Konut", "Türkiye'de Konut Tasarımlarında Sosyal Sinıf Ayrımları Yönünden Uygulanabilir Illkeler" ve "Sosyolojik Açıdan Türkiye'de İlköğretim”, makaleleri örnek olarak verilebilir.

\section{9 ve Sonrası: Baykan Sezerli Yıllar}

1967 y1lında yayın hayatına ara veren derginin bu tarihten tam 22 y1l sonra 1989'da yayınlanan ilk sayısında Baykan Sezer'in "Türk Sosyologları ve Eserleri I" makalesinin olduğunu görüyoruz. Bu durum artık ülkemizde sosyolojik bir birikimin ve kendi milli sosyologlarımızın olduğunun bir işareti olarak görülebilir. Yine Oya Okan'ın “Sosyologlarımız ve Tarihi Gerçekler Önünde Prens Sabahattin” ve Recep Ertürk'ün “Cumhuriyet Döneminde Bir Le Playcr: Tahsin Demiray" makaleleri buna örnek olarak verilebilir.

Ercan'a (2013: 153) göre, bu dönemde mikro sosyoloji çalışmalarının yanı sıra makro sosyoloji çalışmaları yeniden önem kazanmaya başlamıştır. Kadın ve aile, sosyo-ekonomik değişme, Türk sosyoloji tarihi, siyaset, din, hukuk, basın, iletişim, kentleşme, göç, sanayileşme ve gecekondu gibi konular bu dönemde çalışılan konu başlıklarıdır.

Baykan Sezer'in bölüm başkanlığına geldiği ve dergi editörlüğünü yürüttüğü bu dönemde derginin çizgisi Sezer'in görüşleri çerçevesinde belirginleşmiştir. Bu dönemde makale yazarlarının büyük kısmının İstanbul Üniversitesi Sosyoloji Bölümü üyesi olduğu görülmekte ya da İstanbul ekolüne yakın sosyologların yazılarına yer verilmektedir. Bu dönemde önceki dönemlerden farklı olarak Batı sosyolojisine eleştirel yaklaşılmakta ve yerli bir sosyoloji anlayışı savunulmaktadır (Ercan, 2013: 196-197).

1989 yılından sonra 1990 yılında yayınlanmayan ve 1991 yılında genel sosyoloji teorilerinin hâkim olduğu dergide köy monografileri dışında alan araştırmalarının ilk örneklerinin yapıldığını görüyoruz. Erhan Atiker' in "Frankfurt'ta Türk İş̧̧i Gençliğinin Yabancılaşma Sorunu” makalesi ve Ziya Özcan, Ali Çağlar ve Recep Gültekin'in "Polis Akademisi Öğrencilerinin Sosyo-Ekonomik Geçmişleri” adlı makaleleri buna örnek verilebilir.

1992 yılına gelindiğinde ilginin giderek farklılaştı̆̆ 1 ve daha güncel konulara -çizgi roman ve basın gibi- yer verildiği görülmektedir. Ertan Eğribel'in (1992) "Çizgi Roman Olayl ve Toplum", Hayati Tüfekçioğlu'nun "Cumhuriyet İdeolojisi ve Türk Basını", Ufuk Özcan "Kadro Hareketi Üzerine Sosyolojik Bir Deneme”, Mahmut Arslan'1n “Kutadgu-Bilig Üzerine Sosyolojik 
Düşünceler”, "Niccolo Machiavelli ve Machiavelizm” ve Erhan Atiker'in “Örgütlerin Gelişme Süreci ile Kişilik Yapıları Arasındaki İlişkiler” gibi çeşitli konularda makaleler kaleme alınmıştır.

1995 yılında tarih yazıcılığı, Amerikan düşün geleneğinden pragmatizm, eğitimde Batıcılaşmanın eleştirel değerlendirmesi ve Türkiye'deki sosyolojik çalışmaların dönemsel değerlendirmelerini kapsayan çalışmaların olduğu görülmektedir. Erhan Atiker'in "Amerikan Pragmatizmi ve Güncel Yaşam Dünyası”, Ufuk Özcan'ın “Wilson Prensipleri Üzerine”, Ertan

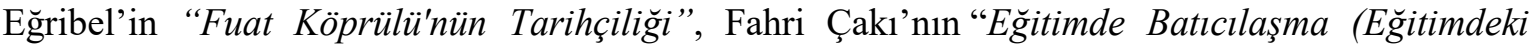
Yeniliklere İlişkin Açıklamaların Eleştirisi)”, H. Bayram Kaçmazoğlu'nun “Türkiye'de Sosyoloji Çalışmaları: 1950-1960 Dönemi”, Ümid Meriç Yazan'ın "Türkiye'de Kadın ve Sosyo-Ekonomik Analizi", Sultan K. Turner'ın "Londra'da Yaşayan Türklerin Integrasyonu ve Ingilizlerle Evlilikleri" ve Zeynep Karahan'ın "1991 Erken Genel Seçimleri ve Reklam Ajansları'nın Etkinlikleri" makalelerine yer verilmiştir. Ayrıca, Alain Touraine'nin Modernliğin Eleştirisi, Ziya Gökalp'in Limni ve Malta Mektupları ve Hilmi Ziya Ülken'in Türkiye'de Çağdaş Düşünce Tarihi kitaplarının değerlendirmelerinin olduğu da görülmektedir.

4 yıl aradan sonra 1999 yılında çıkan sayıda II. Dünya Savaşı sonrası dönemin Japon Batılılaşmasına etkisi, Cumhuriyet dönemi tarihçiliği, arkeolojinin etkisi ve üniversitelerin durumu, kamuoyu ve insan hakları üzerine çalışmalar, Moreno'nun sosyometri çalışmalarındaki yeri, Marco Polo'nun Doğu gözlemleri ve üniversite gençliğinin psiko-sosyal eğilimleri gibi farklı konuların yer aldığı görülmektedir.

\section{0'li Yıllarda Genel Eğilim}

2003 yılına gelindiğinde Korkut Tuna'nın “Küresel mi/Yerel mi: Neler Oluyor Bize?” ve Mehmet Aysoy'un "Sosyal Teoride Küresel Toplum Fenomeninin Imalart" makaleleri bu dönemdeki küreselleşme tartışmalarının yansıması olarak görülebilir. Ayrıca bu dönemde yoksulluk üzerine bazı çalışmaların da olduğunu görmek mümkündür. Bu konuda Ayşen Şatıroğlu'nun "Kent Merkezinde Yoksullaşan Bir Bölge Tomtom Mahallesi" ve Yoksulluk Sempozyumu değerlendirmeleri ve Yücel Bulut'un "Yoksulluk Sorunu Üzerine İki Çalışma" adlı makalesi bulunmaktadir.

2003 yılında sivil toplum, sömürgecilik, modernleşme, ütopya, küreselleşme-yerelleşme, yoksulluk, özne, delilik ve rasyonellik gibi çeşitli konulara yer verilmiştir. Konu çeşitliliğinde gözle görülür ve dikkat çeken bir artışın olduğu aşikârdır. 2004 yılına baktığımızda şehir sempozyumu bildirilerine ayrılan ikinci sayıda (sayı 9) ütopya ve kent ilişkisinden, mezarların kente etkisine, şehir ve planlama tartışmasından çocukların gözünden şehir hayatına kadar çeşitli alanları kapsayan oldukça ilginç konulara yer verilmiştir. Aynı yıl yayınlanan ilk sayıda ise (sayı 8) gerçekliğin inşası, ötekilik problemi, oryantalizm, Ziya Gökalp ve kentsel dönüşüm gibi konulara değinilmiş, ayrıca Simmel'in Modern Kültürde Çatışma kitabının bir değerlendirmesi de yapılmıştır.

2005 yılının ilk sayısı "Türkiye'de Sosyoloji: Ziya Gökalp Sempozyumu” ismiyle çıkmış ve sayıda Ziya Gökalp'e farklı açılardan yaklaşan makalelere yer verilmiştir. Türkiye'de sosyoloji biliminin kuruluşunda 1914 yılında İstanbul Üniversitesi'nde ilk sosyoloji dersini veren Gökalp, şüphesiz sosyoloji alanında ilk akla gelen isimlerdendir. Türkiye'de Durkheim geleneğinin önemli savunucularından olan Gökalp'in hars-medeniyet ayrımından kültürel alandaki birçok önemli konuya ilişkin yaptığı çalışma hem kuramsal hem de pratik açıdan sosyolojinin ülkemizde yerleşmesine katkı sunmuştur. İstanbul Üniversitesi'ndeki bu etkisi derginin özel sayısına da yansımıştır. Nitekim söz konusu yılda çıkarılan ilk sayıda Gökalp'in Batı medeniyetini yorumlama biçimini Yılmaz Özakpınar "Ziya Gökalp’in Batı Medeniyetine Bakışı”"nda, toplumsal bütünleşmeyi Erhan Atiker "Ziya Gökalp'in Düşüncesinde Toplumsal Bütünleşme”'de, Orhan Türkdoğan “Gökalp Sosyolojisinde Aydın Sinıfin Yapısı”"yla aydın,, Recep Ertürk "Ziya Gökalp ve Durkheim İlişkisi ve $B u$ ilişskinin Tarifi” yle Gökalp-Durkheim ilişkisini, İnci Enginün'ün "Gökalp'ın Kültür ve Edebiyattaki Etkisi” "çalışmasıyla Gökalp'in önemi ve hars ve medeniyet kavramları ayrıntılı olarak 
tartışılmıştır. Ayıca Gökalp'in Pierre Bourdieu üzerinden okumasını da içeren Aynur İlyasoğlu'nun "Gücün Oluştuğu Alanlarda Kendileri Egemenlik Altındaki Egemenler" Pierre Bourdieu'nün Kavramlarından Yola Çıkarak Ziya Gökalp'e Yeniden Bakış Denemesi” makalesine de yer verilmiştir. 2005 yılının ikinci sayısında ise Köksal Alver'in edebiyat sosyolojisi çalışması olan "Ahmet Hamdi Tanpınar'ın Romanlarında Bakış Açısı" ve Ayşen Şatıroğlu'nun "Edebiyat Sosyolojisi" çalışmalarına, Ümit Meriç’in "Rönesans Avrupa'sında Sosyal Düşünce"si, küreselleşme ve ulus devletin tartışıldığı İsmail Coşkun'un "Küreselleşme ve Ulus Devlet" makalesine, Recep Ertürk'ün "Pozitivizm Üzerine”, günümüz Aleviliğinin sorunları, Amiran Kurtkan Bilgiseven bibliyografyası ve ütopyalar üzerine hazırlanmış bibliyografya ve sosyal sermaye konularına yer verilmiştir. Bu açıdan ikinci sayıda oldukça farklı konuların ele alındığı ve ilgi alanının giderek çeşitlendiği görülmektedir.

1950'li yıllarda Türkiye'deki ve dünyadaki gelişmelere ayrılan 2006 yılının ilk sayısında Türkiye'de sosyoloji ve edebiyatın 1950'li y1llardaki ilgileri ve o dönem düşünürlerinin önemine değinilmiştir. Esasında bu sayı 21-22 Aralık 2005 yılında İstanbul Üniversitesi Edebiyat Fakültesi Sosyoloji bölümünün gerçekleştirmiş olduğu 1950'li yılları değerlendiren toplantısındaki makalelerden oluşmaktadır. Bu bağlamda, 1950'li yıllarda üniversitelerin genel durumunun tartışıldığı Süha Güney'in “Anılarda Ellili Ylllar ve Üniversite”, çok partili yıllar ve Demokrat Parti deneyimini ele alan Rıdvan Turhan'ın "Yeni Partiler ve Demokrat Parti'nin Seçim Başarısı" makalesine, edebiyat sosyolojisi bağlamında romanda 50'li yılların temsili ve bibliyografyasını içeren Serdar Güler'in “Cumhuriyet Romanında Yeni Bir Dönem: 1950'li Yıllar” ve Köksal Alver'in "Türkiye'de Edebiyat Sosyolojisi Literatürü -Bir Bibliyografya Denemesi", oryantalizm çalışmaları, Şerif Mardin, Mehmet Emin Erişirgil ve Prens Sabahattin'in sosyolojimize katkıları gibi konulara yer verilmiştir. Derginin 2006 yılının ikinci sayısı ise yine 2005'te olduğu gibi Ziya Gökalp'in doğumu münasebetiyle Gökalp'e ayrılmıştır. Sayı içeriğinde Gökalp'in Türk edebiyatındaki yeri, iktisat görüşü, tarih anlayışı gibi konuların yanı sıra dosya konusu dışında çocukların uyum problemi, kent sosyolojisi ve nitel araştırma tekniğine dair farklı konular da yer almaktadır. Dergideki bazı makaleler şöyledir: Tülay Kaya ve Ridvan Turhan, "Ziya Gökalp'in Yaşam Öyküsü”, Cemal Aksu "Ziya Gökalp ve Türk Edebiyatındaki Yeri", Mehmet Beyhan "Ziya Gökalp'in Tarih Anlaylşı ve Türk Medeniyeti Tarihi Adlı Eseri”, Recep Ertürk "Ziya Gökalp'in Sosyoloji Mirası Üstüne”.

2007 yılına baktığımızda genel olarak teorik çalışmaların yanında pratiğe-alana yönelik çalışmalara da yer verildiği ve biraz daha Batı sosyolojisinin uygulama eğilimine yakın konuların ele alındığ1 görülmektedir. Immanuel Wallerstein'ın entelektüel gelişiminden Ulrich Beck'in risk toplumuna, sokakta çalışan çocuklara yönelik alan çalı̧̧masından sosyal psikoloji, gerçekliğin sosyal inşası (2 makale) ve yeni bir sosyal bilim inşa çabası tartışması gibi konulara kadar farklı mecralardan geniş bir konu yelpazesiyle karşılaşılmaktadır. Bu sayıda Nalan Yetim ve Mustafa Çağlayandereli’nin “Toplumsal Algl Boyutuyla Sokakta Çalışan Çocuklar: Mersin Örneği””ni, Lütfi Sunar'ın “XIX. Yüzyll Avrupa'sinda Emperyalizm Algısl”n1, Tülay Kaya'nın “Immanuel Wallerstein: Eserleri Çerçevesinde Entelektüel Gelişimi”"ni, Meltem Narter'in “Sosyal Psikolojinin Sosyal Kavramına Dair Öneriler”ini, Mustafa Şan'ın “Sosyal Bilimleri Yeniden Kurgulamak: Avrupa-Merkezci Yaklaşımların Aşılması Çabaları”nı ve Lütfi Sunar'ın "Batı Düşüncesinde Yeni Arayışlar ve Roy Bhaskar'ın Eleştirel Realizm Felsefesi" gibi makalelerini görmek mümkündür.

"Sosyoloji ve Diğer Bilimler Özel Sayısı" olarak yayınlanan ve disiplinler arası bir çabanın ürünü olan 2008 yılının ilk sayısında sosyolojinin diğer disiplinlerle olan ilişkisine değinen, İsmail Coşkun'un "Sosyoloji, Antropoloji, Şarkiyatçıllk ve Öteki” makalesi, sözlü tarihi ele alan Aynur İlyasoğlu'nun "Toplumsalın İçinde Kurgulanan Öznenin Kendini Dile Getirme İmkânları Olarak Yaşam Anlatıları ve Sözlü Tarih” çalışması, modernliğin yarattığı özne ve öznellik kavramlarına yönelik eleştirileri içeren Besim Dellaloğlu'nun “İnsan Bilimleri, Özne ve Öznellik”, psikoloji ve iktidarın kendini psikolojinin dili üzerinden nasıl hâkim kıldığını ele alan Sibel Arkonaç'ın "İktidarın Dili: Psikolojinin Dili" çalışması, sosyolojiye giriş kitapları üzerine bibliyografya ve 
liselerdeki sosyoloji kitapları üzerine değerlendirmeleri içeren yazıların yanı sıra Wallerstein, Kindleberger ve Şirin'in kitap eleştirilerinin olduğu üç kitap değerlendirmesi de yer almaktadır. Ayrıca ikinci sayıda ise Ayşe Azman'ın "Niyazi Berkes: Ulusçuluk-Devrimcilik Ekseninde Kemalist Çağdaşlaşma Modelinin İnşası", Şennur Özdemir'in "Karşılaştırmalı Bir Perspektiften Kapitalizm ve Kültür”, Süha Göney'in "Türkiye ve Avrupa Birliği”, Özlem Sertkaya Doğan'ın “Türkiye'nin Tarım Politikalarının Belirlenmesinde Coğrafi Özelliklerin Önemi" ve sosyoloji-siyaset ilişkisini içeren Coşkun San'ın “Türkiye'de Siyasetin Gölgesinde Sosyoloji Bilimi”” gibi yazılar da yer almıştır.

2009 yılına gelindiğinde ise derginin ilgi alanında ütopyalara kayıldığ 1 görülmektedir. Ütopyalara ayrilan makaleler arasında Murad Omay'ın "Ütopya Üzerine Genel Bir Inceleme”sini, Çiğdem Dürüşken'in “Uzaklarda Bir Diyar: Civitas Solis”ini, Mehmet Bayartan'ın “Ütopyalarda Coğrafi Mekânı" "nı, Köksal Alver'in “Ütopya: Mekan ve Kentin İdeal Formu”nu, Akın Sevinç'in "Hayal Gücüne Güç Katan Toplumsal Arka Plan: 1960'ların Ütopya Eskizleri Iç̧in Altlık Çalışması" "nı ve Shakespeare'in Firtına oyunu ile ütopyalar arasındaki benzerlik ve farklılıklarının ele alındığı Kerem Karaboğa'nın "Shakespeare'in Ütopyasında Siyaset ve Toplumsal DüzenFırtına'nın Düşündürdükleri” çalışmasını görmek mümkündür. Ütopyayla ilgili bu makalelerin dışında yoksulluk çalışmalarının Türkiye'deki seyrini değerlendiren Murat Şentürk'ün "Türkiye'de Yoksulluk Çalışmaları" ve Ahmet Kanlıdere'nin "Yusuf Akçura ve Kuzey Türkleri” ni ele alan iki makaleye yer verilmiştir. Derginin ikinci sayısı ise "İlerleme Özel Sayısı" olarak yayınlanmıştır. Medeniyetin anlam haritasının çıkarılmaya çalışıldığ Medeniyetin Gelişmesi ve Anlamının Tarihi”, Ömer Soykan'ın ilerlemenin modernite ve anarşizm ile ilişkisini ele aldığ1 "Modernite ve Anarşizmle İlgisi Bakımından İlerleme Kavramının Bir Çözümlemesi”, Türkiye'de modernleşmenin öncü kurumlarının tartışıldığı Mustafa Kaçar'ın "Türkiye'de Modernleşmenin Öncü Kurumlart”, Yücel Bulut'un "Osmanll'dan Cumhuriyet'e Pozitivizm, Terakki ve Batılılaşma Meselelerine Dair" çalışmalarına rastlanmakta, ayrıca Erhan Atiker'in "Kayıt Dışı Ekonomi”, Ufuk Özcan'ın "1980 Sonrasında Türk Sosyolojisinde Değişen Temalar Üzerine Bazı Gözlemler” ve İsmayıl Hakkı Baltacığlu ve Aynur Erdoğan'ın “İçtimaiyat Tahsil Etmek İsteyen Gençlere” "çalışmaları da yer almıştır.

2010 yılının ilk sayısında, İstanbul esnafının dilencilik olgusuna bakış açısının saha araştırmasına dayalı olarak değerlendirildiği İsmail Coşkun ve Alev Erkilet'in "Kapıya Geleni Geri Çevirmeme: İstanbul Esnafinın Dilencilik Olgusuna Bakış Açısı", Suvat Parin'in "DilencilikYoksulluk Illişkisi”, Cüneyd Dinç'in "Birleşmeden Sonra Alman Sosyolojisi”" çalışması, Yusuf Adıüzel'in "Diyasporadaki Kimlik Algılamalarına Göç Tipinin Etkisi: Almanya ve İngiltere Türk Toplumlarının Karşılaş̧ırması” ve Aynur Erdoğan'ın “Tanzimat Döneminde Yurtdışına Öğrenci Gönderme Olgusu ve Osmanlı Modernleşmesine Etkileri” makalelerine yer verilmiştir. Aynı yılın ikinci sayısı "Durkheim Özel Sayısı" olarak yayınlanmıştır. Durkheim üzerine hazırlanmış birbirinden önemli makalelerle Durkheim düşüncesi ve sosyolojiye katkıs1 ortaya konmaya çalışılmıştır. İştar Gözaydın ve Nazlı Ökten Gülsoy'un Durkheim'ın din düşüncesinin güncel imkanlarını tartıştıkları "Durkheim Sosyolojisinde Dinin Tarihsel ve Güncel Olanakları", Coşkun San'ın "Toplumbilimsel Yöntem Açısından Durkheim ve Weber" tartışması, Doğan Ergun'un Gökalp'e Durkheim ve Weber üzerinden baktı̆̆1 "Sosyolojik Aklın Sosyolojik Eleştirisi ya da Ziya Gökalp'in Yeğlediği” "makalesi, Sibel Arkonaç'ın Wundt ve Durkheim incelemesini içeren "Kollektif Bilinç/Kollektif Temsiller: Wundt ile Durkheim", Durkheim-pragmatizm ilişkisine yoğunlaşan Günce Berkkurt'un "Pragmatizm Eleştirisinden Liberalizmin Kuşatmasina Durkheim Sosyolojisi”, M. Ertan Kardeş, Özden Turhan'ın "Durkheim'da Süreklilik ve Kopuş Olarak Felsefe ve Sosyoloji İlişkisi”ne ve Durkheim bibliyografyasına yer verildiği görülmektedir.

2011 yılının ilk sayısı "Korkut Tuna'ya Armağan” ismiyle çıkmıştır. Sayıda, Korkut Tuna'nın biyografisi, yönettiği tezler, şehir sosyolojisi çalışmaları, İstanbul Üniversitesi Sosyoloji bölümüne yaptığı katkılar, bibliyografyasına kadar çeşitli çalışmalara ve Girit'teki nüfus değişimi, $\mathrm{AB}$ ülkelerinde Türk araştırmalarının gelişimi, yurt dışına işçi gönderimi meselesi, şehir tarihi ve 
sosyolojisi, kent araştırmalarının değişen seyri, Chicago Okulu'nun kent çalışmalarındaki yeri ve önemi, Weber'in şehir sosyolojisi, postmodern Batılı bilginin eleştirisi, evrim tartışması ve Türkiye'de psikanalizin geliş̧imi gibi şehir sosyolojisi dışında da birçok farklı konuya yer verilmiştir. "Batı'da Sosyoloji Eğitimi Özel Sayısı"na ayrılan ikinci sayı dosya konulu çıkmış olsa da diğer dosya konulu sayılarda olduğu gibi dosya konusu dişında da makalelere yer verilmiştir. Yücel Bulut'un "Türkiye'de Sosyoloji Eğitimi”, Cüneyd Dinç ve M. Fazıl Baş’ın "Alman Üniversitelerinde Sosyoloji Eğitimi", Enes Kabakçı'nın "Fransa'da Sosyoloji'nin Tarihi Gelişimi ve Fransız Üniversitelerinde Bugünkü Sosyoloji Müfredatı”, Muhammed Bilici'nin “Ingiltere'de Sosyolojinin Dünü ve Bugünü", Alper Bilgili'nin "Hollanda Sosyolojisi”, Sevim Hacioğlu'nun "Rusya'da Sosyoloji Öğretimi”, İştar Gözaydın ve Nazlı Ökten Gülsoy'un "Günümüzde Durkheim Neden Okunmalı? ” çalışmasının yanı sıra yine Enes Kabakçı'nın "Comte Pozitivizminin Serencamı (18201857): Pozitif Felsefeden İnsanlık Dinine” makalesi gibi çalışmalara yer verilirken çok kültürlülük gibi konular da tartış1lmıştır.

"Oryantalizm Özel Sayısı" ve "Pierre Bourdieu Özel Sayısı" olarak yayınlanan 2012 yılındaki sayılarda birbirinden önemli makalelere yer verilmiştir. Oryantalizm sayısında Türkiye'nin $\mathrm{AB}$ üyeliği sürecinde çıkan haberlerdeki oryantalist izdüşümleri ele alan H. Esra Arcan'ın "Şarkiyatçıllğı̆n Aynasında Türkiye Suretleri: Britanya Basınında Türkiye'nin AB Üyeliğine İlişkin Haberlerde Şarkiyatçı Söylem "i, Aydınlanma döneminde Doğu medeniyetlerine bakışı ele alan Lütfi Sunar'ın "Aydınlanma Döneminde Doğuya Bakış: Değişen Ilgi ve Söylemler”i, Nalan Yetim'in "İş ve Örgüt Yazınında Oryantalist Eğilimler ve "Diğeri"nin Yüzü", İslam sanatına oryantalist yaklaşımları değerlendiren Ayşe Taşkent'in "Arnold, Creswell ve Grabar Metinleri Bağlamındaİslam Sanatı ve Oryantalist Yaklaşımlar Üzerine Bir Inceleme I"i, Oktay Taftalı'nın “Toplum ve Tarih Metodolojisi Bakımından Subjektivizmin Bazı Ípuçları Üzerine” çalışması ve Adem Başpınar'ın İkinci Dünya Savaşı ve Soğuk Savaş dönemlerinde askeri alandaki sosyal-psikolojik çalışmalarla iyice bilimin gündemine yerleşen askeri sosyoloji üzerine Türkiye'deki ilk çalışmalardan olan "Sosyolojinin Konusu Olarak Ordu ve Asker: Askeri Sosyoloji" başlıklı bir çalışmaya yer verilmiştir. Bu sayıda askeri sosyolojiye dair bir yayının olması alanın yeni konuları arasında sayılabilirken gündemin de değiştiğini göstermektedir. Oryantalizme dair derinlikli analizlerin olduğu ilk sayının ardından dergi, "Pierre Bourdieu Özel Sayısı"yla karşımıza çıkmaktadır. Özellikle son yıllarda Bourdieu'ye gösterilen yoğun ilginin derginin de gündeminde olduğunu görmekteyiz. Bourdieu'nün Cezayir deneyiminin Bourdieu'ye etkisini ele alan Nazlı Ökten Gülsoy'un “Cezayir Deneyiminin Pierre Bourdieu'nün Sosyolojik Tahayyülüne Etkileri: Bilimsel Bir Habitusun Doğuşu”, Bourdieu'nün devlet düşüncesini ele alan A. Günce Berkkurt'un "Sosyolojinin Kaçınılmaz Nesnesi Devlet Üzerine: Pierre Bourdieu'nün 1989-1992 Yılları Arasinda Collage de France'da Verdiği Dersler"i, sosyoloji ve tahakküm ilişkisinin irdelendiği Elyesa Koytak'1n “Tahakküme Hükmetmek: Bourdieu Sosyolojisinde Toplum ve Bilim Illişkisi” ve Türkçe'de Bourdieu bibliyografyası çalışmalarına yer verilmiştir. Ancak şunu belirtmek gerekmektedir ki Bourdieu sayısında sadece toplamda dört makale yayınlanmıştır. Bu da bizlere henüz Bourdieu'ye yönelik ilginin istenilen düzeyde olmadı̆̆ını göstermektedir.

2013 yılında Aynur Erdoğan’ın “Tanzimat Dönemi Bilim Alglsı”, Ergün Özgür’ün “Yaşa Göre Değer Farklılıkları ve Siyasi Kuşak Aidiyeti”, Aynur Can'ın Rumelihisarı üzerinden değişim ve kimlik tartışması yürüttüğü "Değişim ve Kimlik Bağlamında İstanbul'dan Özgün Bir Mekânsal Kesit: Rumelihisarl”, Ömer Miraç Yaman ve Mehmet Ali Akyurt'un "Sosyal Hizmete Kültürel Yaklaşım: 2011 Van Depremi Örneği”" gibi makaleler yayınlanmıştır. İkinci sayı ise "Göç Özel Sayısı” olarak yayınlanmıştır. Göç, etnisite ve öteki ilişkisinin değerlendirildiği Betül Duman'ın "Yoğun Göç Almış Metropollerde Etniklik ve Öteki ile İlişki", siyaset ve göçmenlik algısının Eskişehir üzerinden okunmasını konu edinen Yusuf Adıgüzel'in "Dayanışma Ağları Üzerinden Eskişehir'de Siyaset ve Göçmenlik Algısı", evliliğe dayalı göçlere eğilen Ayla Deniz ve E. Murat Özgür'ün "Antalya'daki Rus Gelinler: Göçten Evliliğe, Evlilikten Göçe”, Avrupa'daki Türk 
göçmenlerin aile yapılarını konu edinen Başak Bilecen'in “Avrupa'daki Türkiyeli Göçmenlerin Ulusaşırı Aile Ağları”, Alman-Türk Gençliğinin müzik eğilime odaklanan Serhat Güney vd.'nin "Sokaklardan "Club”lara: Alman-Türk Gençliğinin Müzik Serüveni”, ve Hasan Güler'in "Ağrılı Göçmenlerin Fransa'ya Tutunma Stratejileri” gibi makalelere yer verilmiştir. Bu dönemde göç konusuna yoğunlaşılması derginin özellikle Ortadoğu'da yaşanan gelişmeler neticesinde gündemimizi daha fazla meşgul eden göç ve göçmenlere dair meselelere kayıtsız kalmadığı ve yakından takip ettiğini göstermektedir.

2014 yılındaki sayıları “Türkiye'de Sosyolojinin 100. Yı11 Özel Sayısı I-II”na ayıran dergi, Türkiye'de sosyolojinin tarihsel serüvenini ortaya koyan yazılara yer vermiştir. Enes Kabakçı "Bir Yeniden Yorumlama Örneği: Ahmed Rıza'nın "Pozitivizmi”, Aynur Erdoğan'ın “Meşrutiyet'in Evrimci Dergisi: Ulûm-ı İktisadiye ve İçtimaiye Mecmuası”, Oya Okan'ın “Economics, National Economics and Ziya Gökalp”, Muhammed Baş'ın "Gerhard Kessler'in Türkiye'deki Sosyoloji Anlayışına Katkısı", Mehmet Balcı'nın "Sistem ve/veya Eleştiri: Mehmet İzzet'in Sosyoloji Anlayışı", Feryal Saygılıgil'in "Erken Cumhuriyet Dönemi Aydinlarından: Mediha Esenel (Berkes)", Cem Özatalay'ın "Türkiye'de Ekonomi Sosyolojisi: Bilanço ve Perspektifler”, Lütfi Sunar'ın “Türkiye'de Sosyal Bilimlerde Toplumsal Değişim”, Seda Güven'in “Türkiye'de Sağllk Sosyolojisi Çalışmaları", Serdar Nerse'nin "Türkiye Kır Çalışmalarında Paradigma Değişimi”, Fahri Çakı'nın “Türk Sosyolojisinde Yeni Bir Alan: Gönüllü̈lük Araştırmaları”, Rıdvan Turhan'ın "Türkiye'de Cumhuriyetin Erken Döneminde Max Weber Etkisi ve Bu Etkiyi Anlamak", Abdurrahman Nur ve Elyesa Koytak'in "Mümkün Bourdieu'ler Uzayında Bir Bourdieu: Türkiye Bilimsel Üretim Alanında Bourdieu Sosyolojisi” makaleleri bu sayıda yayınlanan makalelere örnek olarak verilebilir. Necmettin Sadak'ın Durkheim'dan yaptığı çeviriler olan "Içctimaiyatta ve Ulum-ı İçtimaiyede Usul ve Klymet Hükümleri", "Şeniyet Hükümleri", Bougle'den "Sosyoloji Nedir?" ve Sombart'tan "İçtimaiyat Nedir?" gibi önemli çevirilere de yer verilmiştir.

2015 yılındaki ilk sayı "Eğitim Sosyolojisi Özel Sayısı”na ayrılmıştır. M. Ertan Kardeş’in “Aşırt-bireycilik ve Otoritarizm İkileminin Ötesinde Eğitimde Otorite Sorunu”, Tülay Kaya'nın “ABD'de Ev Okulu Uygulamasının Tarihsel Gelişimi ve Bugünkü Durumu Üzerine Bir Değerlendirme”, Mehmet Aysan ve Asil Özdoğru'nun "Avrupa'da Erken Çocukluk Bakımı ve Ĕgitiminin Mukayeseli Analizi”, Gökhan Kılıçoğlu vd.'nin “İngiltere'deki Türk Öğrencilerin Kültürleşme Tercihleri ve Bu Tercihlerin Okula Aidiyet Duygusuyla İlişkisi”, Vehbi Bayhan'ın "Eğitim Sosyolojisinin Uygulama Alanında Yeni Bir Model: Okul Sosyoloğu ve Görevleri", Selahattin Turan vd.'nin "Türk Eğitim Sisteminde Okullar ve Dershaneler: Çoklu Paradigma Açısından Bir İnceleme” bu sayıdaki makalelere örnek olarak verilebilir. Sayıda eğitim hakkından, Gramsci'nin demokratik eğitim modeline, eğitimde otorite sorunundan ABD'de eğitimin durumuna, Japonya'da üniversitelerin bilimsel üretiminden Avrupa'da erken çocukluk dönemi eğitimi, okul sosyoloğu tartışmaları, eğitim sistemimizde dershanelerin rolü gibi farklı konular ele alınmıştır. Derginin ikinci sayısında ise askeri sosyoloji çalışmalarına yer verilmiştir. Son yıllarda ülkemizde askeri sosyoloji çalışmaları alanında ilk olarak bu sayıda alanla ilgili önemli çalışmalara yer verilmiştir. Ancak makalelerin çok da geniş bir alanı kaplamadığını söylemek doğru olur kanaatindeyiz. Zira askeri sosyoloji konusunda 3 makaleye yer verilirken bir de yoksulluk üzerine yazılmış bir çalışma da aynı sayıda yer almıştır. Bu da göstermektedir ki askeri sosyoloji ülkemizde henüz yeterli ilgiyi görememektedir. Örnek vermek gerekirse, David R. Segal'in "Modern Ordu Teşkilatında Çeşitlilik ve Vatandaşlık”, Remi M. Hajjar'ın “ABD Nizami Silahlı Güçlerinin Yürüttü̈̆̈̈̈ Gayrinizami Askerî Danışmanlık Görevi”" ve Nicholas L. Bremner ve İrina Goldenberg'in "Kanada Silahlı Kuvvetlerinde Liderlik, Algllanan Örgütsel Destek ve Örgütsel Băglllı: BireyÖrgüt Uyumunun Aracı Rolü”.

2016 yılına gelindiğinde derginin daha çok çalışma, meslek hayatı, orta sınıf ve yeni orta sınıf ilişkisi, enformasyon toplumu, Pitirim Sorokin'in toplumsal hareketlilik düşüncesi ve tabakalaşma ağırlıklı konuların işlendiği görülmektedir. Kadınların çalışma yaşamındaki 
konumundan Mersin'deki Romanlar'ın toplumsal hareketlilik ve dışlanma karşısındaki durumlarına kadar birçok konu ele alınmıştır. Meltem Yılmaz Şener'in "Kadınlar Altın Yaka Takabilir mi? Türkiye'de Eğitimli Kadınlar İçin İş Hayatı", Sibel Erdoğan Demir'in "Enformasyon Toplumu ve Yeni Orta Sinıflar", Neriman Açıkalın ve Burak Şahin'in "Burada Her Şey Kendiliğinden": Mersin'de Yaşayan Romanlar Üzerine Alan Araştırması", Irmak Karademir vd.'nin "Kuşak-içi ve Kuşaklararası Toplumsal Hareketliliğin Yörüngesi: Ankara İli Örneği”, M. Fatih Karakaya'nın "Son Klasik, Illk Modern: Pitirim Aleksanroviç Sorokin ve Toplumsal Hareketlilik" ve Merve Betül Üçer'in "Sinıflar ve Duyguları: Tabakalaşma Çalışmalarında Duygulara Yer Açmak" makaleleri örnek olarak gösterilebilir. Bu sayıda Merve Betül Üçer'in duygular sosyolojisi çalışması da ülkemizde yeni gelişen bir alana yaptığı katkı açısından önem taşımaktadır. Sayıda yer alan kitap tanıtım yazıları da sınıf ve eşitsizlik tartışmaları üzerine yoğunlaşmaktadır. Yaşlanma sosyolojisine ayrılan ikinci sayıda ise yaşlılık konusu derinlemesine analiz edilmeye çalışılmıştır. Yaşlılık ve yerel yönetimler ilişkisinin ele alındığı Özgür Arun ve Çağrı Elmas'ın "Yaşlılıkta Ayrım: Çağdaş Türkiye'de Yerel Yönetimleri Bekleyen Zorluklar", yaşl1lıkta çalışmaya odaklanan Seda Topgül'ün "Çalışma Yaşamında Yaşlı Ayrımcılığı mı Yaş Ayrımcılı̆̆ı mı?”, Şerif Esendemir'in "Türkiye'de Yerinde Yaşlanma ve Mekân Gerontolojisinin Temel Parametreleri", Özgür Kılınç ve Ferruh Uztuğ'un "Televizyon Dizilerinde Yaşlılığın Temsili” gibi çeşitli konulara yer verilmiştir.

Derginin ilgi alanının 2017'de müziğe kaydığı görülmektedir. 2017 yılında çıkan iki sayı da müzik sosyolojisine ayrılmış ve farklı konulara yer verilmiştir. Selman Benlioğlu'nun "Modernleşme Sürecinde İktidar-Müzisyen İlişkisi: III. Selim ve II. Mahmud İçin Bestelenen Medhiyeler", Akın Kiren'in "Nasirüddin Şah Dönemi Iranı'nda (1848-1896) Modernleşme ve Meşruiyet Araçlarından Biri Olarak Müzik”, Z. Gülçin Özkişi'nin "Ekspresyonizm ve Müzik: 20. Yüzyılın Illk Yarısında II. Viyana Okulu Çevresinde Gelişen "Yeni Müzik" Yaklaşımı ve Müzikal Modernizm" makalelerde Osmanlı'da iktidar-müzisyen ilişkisi, İ́an ve Yunanistan'da müziğin gelişimi, müzikal modernizm, Çin'de müzik ve ritüel, klasik Yunan müziğinin sosyolojisi, Osmanlı müziğinde klasik üslup gibi konular irdelenmiştir. Burada iktidar, sanat ve müzik ilişkisi ele alınmıştır. Müziğin İran, Yunan ve Osmanlı'daki kökenleri irdelenirken iktidarla olan ilişkisine de değinilmiştir. Benzer bir eğilimin 2018 yılının ilk sayısında da olduğunu görmekteyiz. 2018 yılının ilk sayısında da müzikle ilgili özel bir dosya hazırlanmış ve müziğin çeşitli alanlarla ilişkisi yorumlanmıştır. Arabesk müziğin dönüşümü tartışmasından protest müziğe, müziğin antropolojik kökenlerinden göç ve ötekilikle olan ilişkisine kadar birçok farklı alanda geniş bir müzik sosyolojisi gerçekleştirilmeye çalışılmıştır. Sayının müziğe ayrılmış olması, Türkiye'de sosyolojik ilginin giderek farklı alanlara kaydığının ve sosyolojinin daha ilişkisel ve disiplinler arası bir yöne doğru değişim gösterdiğinin bir işaretidir. 2018'in ikinci sayısı ise, kültürelcilik, gelişmecilik, medeniyet tartışması ve Avrupa Birliği gibi konularını içermektedir. Mehmet Ali Akyurt'un "Alman Tarihçiliğinin Alameti Farikast "Devlet Merkezlilik midir?", Parsons'1n medeniyet tasavvurunun tartışıldığ 1 Mehmet Emin Balcı'nın “Sinır-Ötesi Bir Uygarlık Operasyonu: Talcott Parsons'ın Uygarlı Okuması" makalesi, M. Fatih Karakaya'nın "Bütünleşmiş Kültürün Toplumsal Dinamikleri: Sorokin 'in Uygarlık(lar) Okuması" gibi çeşitli yazıları yer almıştır. Son dönem özelikle $\mathrm{AB}$ 'ye giriş ve $\mathrm{AB}$ 'nin dağılması tartışmaları bağlamında değerlendirildiğinde bu sayının medeniyet, gelişmişlik ve tarihselcilik tartışması yürütmesi oldukça anlamlıdır.

2019 yılında yayınlanan ilk sayı Emile Durkheim'a ayrılmış özel bir sayı olarak karşımıza çıkmaktadır. Durkheim'a olan ilginin nedenlerinden başlayarak bir yandan Durkheim'ın teorik düşüncesini anlamaya yönelen makaleler diğer yandan ise ulus ve çevre gibi bazı meselelere Durkheim üzerinden bakmaya imkân tanıyacak yazılara yer verilerek Durkheim'ın teori ve pratik karşıllğı anlaşılmaya çalışılmıştır. Bu sayı, özellikle son yıllarda dünyada da artan Durkheim ilgisinin Türkiye'deki yansıması olarak okunabilir. Sayıda Aynur Erdoğan Coşkun ve Philip Smith'in Editörden yazısı olan "Durkheim Üzerine Dört Tip Entelektüel Üretim Biçimi ve Türkiye'deki Durkheim Yansimalarl” makalesi, Alexander Goffman'ın "Tradition, Morality and Solidarity in 
Durkheim's Theory"si, Eric Malczewski'nin “Durkheim and the Nation”, Çağrı Eryılmaz'ın "Durkheim'da Toplum-Çevre Etkileşimi: Dışlayıcı Toplumsal Olgulara Karşı Çevreci Potansiyel”i ve Abdülkerim Sönmez'in "Durkheim'in Toplumu Bir Özne, Toplumsalı Bir Nesne Olarak Kavramsallaştırma Çabası" gibi makalelere yer verilmiştir.

\section{Sonuç}

Türkiye'de sosyolojinin kurumsal kimlik kazandığı İstanbul Üniversitesi, en eski ve en köklü sosyoloji dergisinin de ilk ortaya çıktı̆̆ yer olarak Türk sosyoloji tarihinde önemli bir yere sahiptir. Türkiye'de sosyolojinin ortaya çıkması ve gelişmesindeki önemli rolü dergiyi, Türkiye'deki sosyolojinin kurumsallaşmasından günümüze kadarki değişen eğilimlerini anlamamızda bir çalışma nesnesine dönüştürmüştür. Sosyolojinin İstanbul Üniversitesi Sosyoloji Dergisi üzerinden -o dönemki adıyla İçtimaiyat Mecmuası- ülkemize aktarımının sağlanmış olması Türkiye'deki ilk görünümlerinin aktarmacı bir anlayışla yapıldığı ithamına neden olmuştur. Her ne kadar dergi, Batı'dan aktarılan ilk bilgilerle şekillenen sosyolojinin dışa bağımlı karakteriyle ve Batı aktarmacılığıyla itham edilse de ilk yayınlandığı sayıdan itibaren ülkenin içinde bulunduğu sorunlara çözüm üretme gayesiyle hareket ederek milli bir tavır takındığını da belirtmek gerekmektedir. Bu durum İstanbul Üniversitesi Sosyoloji Dergisi'nin özgün olma çabalarının ve kendi toplumunun sosyolojisini kurmaya çalışmasının bir işaretidir.

Sosyoloji Dergisi'nin toplumsal sorunlara çözüm üretme amacıyla ortaya çıkması Batı sosyolojisinin ilk dönemlerinde tartış1lan toplumsal uyum, denge ve düzen arayışı çerçevesinde bir sosyoloji üretme yoluna gidildiğini göstermektedir. $\mathrm{Bu}$ bağlamda uyum ve denge üzerine düşünceleriyle bilinen Fransız sosyolog Emile Durkheim'ın derginin ilk dönem yazılarına açık bir şekilde etki ettiğini söylemek mümkündür. Dolayısıyla bu dönemde işlevsel sosyolojinin ilk öncü isimlerinden olan Durkheim'ın kavram ve metodolojisinin dergiye hâkim olduğunu söyleyebiliriz.

Derginin yayın stratejisinde dönem dönem bazı isimlerin açık bir şekilde etkin olduğu görülmektedir. Örneğin derginin ilk dönem yazılarında Ziya Gökalp'in bariz bir etkisinin olduğu görülmüş, Gökalp'in sosyoloji kürsüsünü kurması ve dolayısıyla dergi editörlüğünü üstlenmesi onun çizgisinde daha milli bir sosyolojik bilgi üretiminin yolunu açmıştır. Nitekim Ziya Gökalp'in Milli İçtimaiyat adı altında Türk toplumunun sorunlarına çözüm üreten milli bir sosyoloji kurma düşüncesiyle hareket ettiği bilinmektedir. Daha sonra derginin ikinci dönem yazılarında -1941'den itibaren- Hilmi Ziya Ülken'in ağırlığının arttığını belirtebiliriz. Bu dönemde ülkedeki genel sosyolojik ilginin, derginin yazılarına da yansıdığı görülmektedir. Nitekim bu dönemde Ankara Üniversitesi'nin Amerikan sosyolojisine yakın çalışmaları dergide de yansımalarını bulmuş; bu yönde bazı çalışmalar yapılmıştır. Ama yine de sosyoloji dergisinde Fransız sosyolojisinin etkilerinin halen devam ederek genel çizgisini koruduğunu belirtebiliriz. 1989'da Baykan Sezer editörlüğünde tekrar yayınlanmaya başlayan dergide önceki dönemlerden farklı olarak Batı sosyolojisine eleştirel yaklaşılmakta; yerli bir sosyoloji anlayışı savunulmakta ve "Doğu-Batı Çatışması" tartışmaları hız kazanmaktadır. Böylece dışa bağımlı ve aktarmacı sosyoloji geleneğinden sıyrılarak Türk sosyolojisinin kendi imkânlarını kullanma ve sorgulama olanağı doğmuştur.

Dergide, dünyada ve Türkiye'de meydana gelen önemli toplumsal değişmeler ve sorunlar çerçevesinde bir sosyolojik bilgi üretimi yapıldığı görülmektedir. Başka bir deyişle hem dünyadaki tartışmalar hem de Türkiye'nin içinde bulunduğu toplumsal değişmelere bağlı sorunsallar derginin yazarlarının ele aldığı konulardandır. Örneğin Türkiye'deki ekonomik ve sosyal hayatın önemli kırılma noktalarından biri olan 1950'li yıllarda köyden kente göçün yoğunlaşması buna bağlı olarak kentleşmeyle birlikte ortaya çıkan değişim ve dönüşümler derginin yazılarında karşılık bulmakta hem köy monografileri hem de kentleşmeyle ilgili yazılara yer verilmektedir. Yine 2000'li yıllarda küreselleşme, modernleşme, yoksulluk tartışmalarıyla ilgili yazıların var olması bu duruma örnek verilebilir. 
2004 ve sonrasında derginin genel olarak bir dosya konusu çerçevesinde yazılara yer vermeye başladığı görülmektedir. Bu açıdan bazen bir sempozyumun bildirilerini toplayarak bazen bir çalıştayda sunulan çalışmaların derlenmesiyle bazen de özel olarak bir dosya konusunun belirlenmesiyle tematik bir dergicilik anlayışı ortaya konulduğuna şahit olmaktayız. Belirlenen temalar derginin genel sosyolojik eğilimi hakkında bize ipuçları vermektedir. Bunlar; Türkiye'de sosyoloji, Ziya Gökalp, sosyoloji ve diğer bilimler, ütopya, ilerleme, Durkheim, Korkut Tuna'ya armağan, Batı'da sosyoloji eğitimi, oryantalizm, Pierre Bourdieu, göç, Türkiye'de sosyolojinin yüzüncü y1lı, eğitim sosyolojisi, yaşlanma sosyolojisi ve müzik sosyolojisi olarak sıralanabilir. Belirlenen temalar içerisinde Ziya Gökalp ve Durkheim'e karşı özel bir ilginin halen devam etmekte olduğunun da belirtilmesi gerekmektedir. Çünkü farklı yıllarda aynı temada dergi sayıları çıkmaktadır. Bu durum derginin bahsi geçen temaları canlı tutmak istediğinin de bir göstergesidir. Böylece derginin kurucu babası olan Ziya Gökalp ve onun izlediği sosyoloji geleneğinin kurucusu olan Emile Durkheim'in İstanbul Üniversitesi Sosyoloji Dergisi açısından önemini koruduğu anlaşılmaktadır. Yine derginin son sayısının da Durkheim üzerine olması özellikle son yıllarda dünyada da artan Durkheim ilgisinin Türkiye'deki yansıması olarak okunabilir. Bununla birlikte eğitim, yaşlanma, göç, müzik ve askeri sosyoloji çalışmalarına yer verilmesi giderek ilginin farklı alanlara ve sosyolojinin daha ilişkisel ve disiplinler arası bir yöne kaydığının da göstergesidir. Özellikle son sayılarda göç, yaşlanma, müzik ve askeri sosyoloji gibi konulara yönelinmesi, günümüzde sıkça tartışlan yaşlanmanın, Suriye'deki savaş nedeniyle yaşanan göçün ve askeri sosyolojinin öneminin gözden kaçmadığını ve güncel meselelere yoğunlaşıldığını göstermektedir.

Sonuç olarak dergi kurulduğu ilk günden bugüne değin Türkiye'deki sosyolojik bilginin üretim merkezlerinden biri olarak önemli bir işlevi yerine getirmiştir. Sosyolojinin kurucu isimlerinin izlerinin hâkim olduğu dergide, toplumsal düzen meselesi uzun bir dönem ele alınmş, teorik ve pratik birçok farklı konu ele alınarak ülkenin karşı karşıya olduğu düşünülen sorunlarına çözümler üretilmeye çalışılmıştır. 2000'li yıllardan itibaren dünyadaki siyasal ve kültürel iklimdeki değişimlere bağlı olarak ele alınan konular çeşitlenmiş ve bir yandan klasik diğer yandan da daha güncel meseleler tartışılmaya başlanmıştır.

\section{Kaynakça}

Açıkalın, N, Şahin, B. (2016). "Burada her şey kendiliğinden": Mersin'de yaşayan Romanlar üzerine alan araştırmas1. Istanbul Üniversitesi Sosyoloji Dergisi, 36(1), ss. 71-97.

Adıgüzel, Y. (2011). Diyasporadaki kimlik algılamalarına göç tipinin etkisi: Almanya ve İngiltere Türk toplumlarının karşılaştırması. İstanbul Üniversitesi Sosyoloji Dergisi, 3(20), ss. 97-119.

Adıgüzel, Y. (2014). Dayanışma ağları üzerinden Eskişehir'de siyaset ve göçmenlik algısı. İstanbul Üniversitesi Sosyoloji Dergisi, 3(27), ss. 73-94.

Aksu, C. (2012). Ziya Gökalp ve Türk edebiyatındaki yeri. Ístanbul Üniversitesi Sosyoloji Dergisi, 3(13), ss. 15-27.

Akturan, U. (2008). "Doküman incelemesi”, Nitel araştırma yöntemleri Nvivo 7.0 ile nitel veri analizi içinde, (Ed. Türker Baş ve Ulun Akturan), Seçkin Yayınc1lık.

Akyurt, M. A. ve Yaman, Ö. M. (2012). “Türkiye'de kent sosyolojisi çalışmaları”, Kent sosyolojisi içinde, (Ed. Köksal Alver), Hece Yayınları, ss. 179-219.

Akyurt, M, Coşkun, İ. (2019). Alman tarihçiliğinin alameti farikası "devlet merkezlilik" midir? Ístanbul Üniversitesi Sosyoloji Dergisi, 38(2), ss. 293-342

Alver, K. (2012). Ahmet Hamdi Tanpınar'ın romanlarında bakış açısı. İstanbul Üniversitesi Sosyoloji Dergisi, 3(11), ss. 107-119. 
Alver, K. (2012). Türkiye'de edebiyat sosyolojisi literatürü -bir bibliyografya denemesi-. İstanbul Üniversitesi Sosyoloji Dergisi, 3(12), ss. 185-232.

Alver, K. (2012). Ütopya: mekân ve kentin ideal formu. İstanbul Üniversitesi Sosyoloji Dergisi, 3(18), ss. 139-153.

Arcan, H. (2012). Şarkiyatçılığın aynasında Türkiye suretleri: Britanya basınında Türkiye'nin AB üyeliğine ilişkin haberlerde şarkiyatçı söylem. İstanbul Üniversitesi Sosyoloji Dergisi, 3(24), ss. 83-117.

Arkonaç, S. (2012). İktidarın dili: psikolojinin dili. İstanbul Üniversitesi Sosyoloji Dergisi, 3(16), ss. 55-65.

Arkonaç, S. (2011). Kollektif bilinç/kollektif temsiller: Wundt ile Durkheim. İstanbul Üniversitesi Sosyoloji Dergisi, 3(21), ss. 103-113.

Arslan, M. (2012). Kutadgu-Bilig üzerine sosyolojik düşünceler. İstanbul Üniversitesi Sosyoloji Dergisi, 3(3), ss. 131-166.

Arslan, M. (2012). Niccolo Machiavelli ve Machiavelizm. İstanbul Üniversitesi Sosyoloji Dergisi, 3(3), ss. 167-186.

Arun, Ö, Elmas, Ç. (2016). Yaşl1lıkta ayrım: çağdaş Türkiye'de yerel yönetimleri bekleyen zorluklar. İstanbul Üniversitesi Sosyoloji Dergisi, 36(2), ss. 351-372.

Atiker, E. (1991). Frankfurt'ta Türk işçi gençliğinin yabancılaşma sorunu. İstanbul Üniversitesi Sosyoloji Dergisi, 3(2), ss. 127-138.

Atiker, E. (2012). Örgütlerin gelişme süreci ile kişilik yapıları arasındaki ilişkiler. İstanbul Üniversitesi Sosyoloji Dergisi, 3(3), ss.187-212.

Atiker, E. (2012). Amerikan pragmatizmi ve güncel yaşam dünyası. İstanbul Üniversitesi Sosyoloji Dergisi, 3(4), ss. 29-36.

Atiker, E. (2012). Ziya Gökalp'in düşüncesinde toplumsal bütünleşme. İstanbul Üniversitesi Sosyoloji Dergisi, 3(10), ss. 21-27.

Atiker, E. (2011). Kayıtdışı ekonomi. İstanbul Üniversitesi Sosyoloji Dergisi, 3(19), ss. 205-226.

Aysan, M, Özdoğru, A. (2015). Avrupa' da erken çocukluk bakımı ve eğitiminin mukayeseli analizi. İstanbul Üniversitesi Sosyoloji Dergisi, 3(30), ss. 167-194.

Aysoy, M. (2003). Sosyal teoride küresel toplum fenomeninin imaları. İstanbul Üniversitesi Sosyoloji Dergisi, 3(7), ss. 135-154.

Azman, A. (2012). Niyazi Berkes: ulusçuluk-devrimcilik ekseninde Kemalist çağdaşlaşma modelinin inşası. İstanbul Üniversitesi Sosyoloji Dergisi, 3(17), ss. 31-47.

Bal, H. (2016). Nitel araştırma yöntem ve teknikleri/ uygulamall-örnekli, Sentez Yayıncılık.

Balc1, M. (2015). Sistem ve/veya eleştiri: Mehmet İzzet'in sosyoloji anlayışı. İstanbul Üniversitesi Sosyoloji Dergisi, 3(28), ss. 171-194.

Baltacioğlu, İ, Erdoğan, A. (2011). İçtimaiyat tahsil etmek isteyen gençlere. İstanbul Üniversitesi Sosyoloji Dergisi, 3(19), ss. 297-302.

Baş, M. (2015). Gerhard Kessler'in Türkiye'deki sosyoloji anlayışına katkısı. İstanbul Üniversitesi Sosyoloji Dergisi, 3(28), ss. 201-222.

Başpınar, A. (2012). Sosyolojinin konusu olarak ordu ve asker: askeri sosyoloji. İstanbul Üniversitesi Sosyoloji Dergisi, 3(24), ss. 279-314. 
Bayartan, M. (2012). Ütopyalarda coğrafi mekân. İstanbul Üniversitesi Sosyoloji Dergisi, 3(18), ss. 69-95.

Bayhan, V. (2015). Eğitim sosyolojisinin uygulama alanında yeni bir model: okul sosyoloğu ve görevleri. Ístanbul Üniversitesi Sosyoloji Dergisi, 3(30), ss. 255-274.

Benlioğlu, S. (2017). Modernleşme sürecinde iktidar-müzisyen ilişkisi: III. Selim ve II. Mahmud için bestelenen medhiyeler. İstanbul Üniversitesi Sosyoloji Dergisi, 37(1), ss. 45-74.

Berkes, N. (1942). Bazı Ankara köyleri üzerinde bir araştırma, Uzluk Basımevi.

Berkes, N. (1941). “Köy nüfusu”, Yurt ve Dünya Dergisi, 1(4), ss.16-23.

Berkes, N. (1941). “Köy şekilleri”, Yurt ve Dünya Dergisi, 2(7), ss. 7-15.

Berkkurt, A. (2013). Sosyolojinin kaçınılmaz nesnesi devlet üzerine: Pierre Bourdieu'nün 1989-1992 yılları arasında Collage de France'da verdiği dersler. İstanbul Üniversitesi Sosyoloji Dergisi, 3(25), ss. 31-56.

Berkkurt, G. (2011). Pragmatizm eleştirisinden liberalizmin kuşatmasına Durkheim sosyolojisi. İstanbul Üniversitesi Sosyoloji Dergisi, 3(21), ss. 159-178.

Beyhan, M. (2012). Ziya Gökalp'in tarih anlayışı ve Türk medeniyeti tarihi adlı eseri. Ístanbul Üniversitesi Sosyoloji Dergisi, 3(13), ss. 47-61.

Bilecen, B. (2014). Avrupa'daki Türkiyeli göçmenlerin ulusaşırı aile ağları. İstanbul Üniversitesi Sosyoloji Dergisi, 3(27), ss. 235-250.

Bilgili, A. (2011). Hollanda sosyolojisi. İstanbul Üniversitesi Sosyoloji Dergisi, 3(23), ss. 89-110.

Bilici, M. (2011). İngiltere'de sosyolojinin dünü ve bugünü. İstanbul Üniversitesi Sosyoloji Dergisi, $3(23)$, ss. 63-88.

Boran, B. (1942). "Köyde sosyal tabakalaşma”, Yurt ve Dünya Dergisi, 3(17), ss. 125-128.

Bremner, N, Goldenberg, I. (2016). Kanada silahlı kuvvetlerinde liderlik, algılanan örgütsel destek ve örgütsel bağl1l1k: birey-örgüt uyumunun arac1 rolü. İstanbul Üniversitesi Sosyoloji Dergisi, 3(31), ss. 121-143.

Bulut, Y. (2003). Yoksulluk sorunu üzerine iki çalışma. İstanbul Üniversitesi Sosyoloji Dergisi, 3(7), ss. 193-200.

Bulut, Y. (2011). Osmanlı'dan Cumhuriyet'e pozitivizm, Terakki ve batılılaşma meselelerine dair. Ístanbul Üniversitesi Sosyoloji Dergisi, 3(19), ss. 151-166.

Bulut, Y. (2011). Türkiye'de sosyoloji eğitimi. İstanbul Üniversitesi Sosyoloji Dergisi, 3(23), ss. 118.

Can, A. (2013). Değişim ve kimlik bağlamında İstanbul'dan özgün bir mekansal kesit: Rumelihisarı. İstanbul Üniversitesi Sosyoloji Dergisi, 3(26), ss. 77-102.

Coşkun, İ. (2012). Küreselleşme ve ulus devlet. İstanbul Üniversitesi Sosyoloji Dergisi, 3(11), ss. 714.

Coşkun, İ. (2012). Sosyoloji, antropoloji, şarkiyatçılık ve öteki. İstanbul Üniversitesi Sosyoloji Dergisi, 3(16), ss. 11-26.

Coşkun, İ, Erkilet, A. (2011). Kapıya geleni geri çevirmeme: İstanbul esnafının dilencilik olgusuna bakış açısı. İstanbul Üniversitesi Sosyoloji Dergisi, 3(20), ss. 1-21. 
Çakı, F. (2012). Eğitimde batıcılaşma (eğitimdeki yeniliklere ilişkin açıklamaların eleştirisi). İstanbul Üniversitesi Sosyoloji Dergisi, 3(4), ss. 91-130.

Çak1, F. (2015). Türk sosyolojisinde yeni bir alan: gönüllülük araştırmaları. İstanbul Üniversitesi Sosyoloji Dergisi, 3(29), ss. 185-209.

Çelebi, N. (2004). Sosyoloji ve metodoloji yazıları, Anı Yayınc1lık.

Çelebi, N. (2010). "Türkiye'de sosyoloji”, Türk sosyologlarl ve eserleri II- genel eğilimler ve kurumsallaşma içinde, (Ed. Ertan Eğribel ve Ufuk Özcan), Sosyoloji Yıllığı 20, Kitabevi, ss. 52-95.

Çelebi, N., Kızılçelik, S. (2008). “Gerhard Kessler”, Türkiye'de sosyoloji I içinde, Der. M. Çağatay Özdemir, Phoenix Yayınları, ss. 383-404.

Dellaloğlu, B. (2012). İnsan bilimleri, özne ve öznellik. İstanbul Üniversitesi Sosyoloji Dergisi, 3(16), ss. 1-10.

Deniz, A, Özgür, E. (2014). Antalya'daki Rus gelinler: göçten evliliğe, evlilikten göçe. İstanbul Üniversitesi Sosyoloji Dergisi, 3(27), ss. 151-175.

Dinç, C. (2011). Birleşmeden sonra Alman sosyolojisi. İstanbul Üniversitesi Sosyoloji Dergisi, 3(20), ss. 73-94.

Dinç, C, Baş, M. (2011). Alman üniversitelerinde sosyoloji eğitimi. İstanbul Üniversitesi Sosyoloji Dergisi, 3(23), ss. 19-41.

Doğan, Ö. (2012). Türkiye'nin tarım politikalarının belirlenmesinde coğrafi özelliklerin önemi. Istanbul Üniversitesi Sosyoloji Dergisi, 3(17), ss. 91-100.

Duman, B. (2014). Yoğun göç almış metropollerde etniklik ve öteki ile ilişki. İstanbul Üniversitesi Sosyoloji Dergisi, 3(27), ss. 1-24.

Dural1, T. (2011). Medeniyet nedir? medeniyetin gelişmesi ve anlamının tarihi. İstanbul Üniversitesi Sosyoloji Dergisi, 3(19), ss. 1-35.

Durkheim, E. (1917). Fucûrun nehyi ve menşeleri- I. İstanbul Üniversitesi Sosyoloji Dergisi, 1(1), ss. 34-45.

Durkheim, E. (1917). Fucürun nehyi ve menşeleri- II. İstanbul Üniversitesi Sosyoloji Dergisi, 1(2), ss. 71-93.

Durkheim, E. (1917). Fucürün nehyi ve menşeleri- III. İstanbul Üniversitesi Sosyoloji Dergisi, 1(3), ss. 116-131.

Durkheim, E. (1917). Fucürun nehyi ve menşeleri- IV. İstanbul Üniversitesi Sosyoloji Dergisi, 1(4), ss. $178-189$.

Durkheim, E. (1917). Ondokuzuncu asırda Fransa'da içtimaiyyat- I. İstanbul Üniversitesi Sosyoloji Dergisi, 1(4), ss. 156-165.

Durkheim, E. (1917). Ondokuzuncu asırda Fransa'da içtimaiyyat- II. İstanbul Üniversitesi Sosyoloji Dergisi, 1(5), ss. 233-237.

Durkheim, E. (1917). Ondokuzuncu asırda Fransa'da İçtimaiyat (ikinci devre). İstanbul Üniversitesi Sosyoloji Dergisi, 1(6), ss. 257-263.

Dürüşken, Ç. (2012). Uzaklarda bir diyar: Civitas Solisa. İstanbul Üniversitesi Sosyoloji Dergisi, $3(18)$, ss. $15-24$ 
Eğribel, E. (2012). Çizgi roman olayı ve toplum. İstanbul Üniversitesi Sosyoloji Dergisi, 3(3), ss 144.

Eğribel, E. (2012). Fuat Köprülü'nün tarihçiliği. İstanbul Üniversitesi Sosyoloji Dergisi, 3(4), ss. 4960.

Enginün, İ. (2012). Gökalp'ın kültür ve edebiyattaki etkisi. İstanbul Üniversitesi Sosyoloji Dergisi, 3(10), ss. 113-122.

Ercan, R. (2013). Türkiye'de sosyolojinin gelişimi ve eğilimleri, Anı Yayınc1lık.

Erdoğan, A. (2011). Tanzimat döneminde yurtdışına öğrenci gönderme olgusu ve Osmanlı modernleşmesine etkileri. İstanbul Üniversitesi Sosyoloji Dergisi, 3(20), ss. 121-151

Erdoğan, A. (2013). Tanzimat döneminde modern bilim algıs1. Ístanbul Üniversitesi Sosyoloji Dergisi, 3(26), ss. 1-31.

Erdoğan, A. (2015). Meşrutiyet'in evrimci dergisi: Ulûm-1 İktisadiye ve İçtimaiye Mecmuası. İstanbul Üniversitesi Sosyoloji Dergisi, 3(28), ss. 73-91.

Erdoğan Demir, S. (2016). Enformasyon toplumu ve yeni orta siniflar. İstanbul Üniversitesi Sosyoloji Dergisi, 36(1), ss. 41-70.

Erdoğan Coşkun, A, Smith, P. (2019). Durkheim üzerine dört tip entelektüel üretim biçimi ve Türkiye'deki Durkheim yansımaları. Ístanbul Üniversitesi Sosyoloji Dergisi, 39(1), ss. 9-23.

Ergün, D. (2011). Sosyolojik aklın sosyolojik eleştirisi ya da, Ziya Gökalp'in yeğlediği. İstanbul Üniversitesi Sosyoloji Dergisi, 3(21), ss. 41-60.

Erişçi, L. (1941). Türkiye'de sosyolojinin tarihçesi ve bibliyografyası. İstanbul Üniversitesi Sosyoloji Dergisi, 2(1), ss. 159-169.

Ertürk, R. (1989). Cumhuriyet döneminde bir Le Playc1: Tahsin Demiray. Ístanbul Üniversitesi Sosyoloji Dergisi, 3(1), ss. 107-146.

Ertürk, R. (2012). Ziya Gökalp ve Durkheim ilişkisi ve bu ilişkinin tarifi. İstanbul Üniversitesi Sosyoloji Dergisi, 3(10), ss. 81-90.

Ertürk, R. (2012). Pozitivizm üzerine. İstanbul Üniversitesi Sosyoloji Dergisi, 3(11), ss. 1-6.

Ertürk, R. (2012). Ziya Gökalp'in sosyoloji mirası üstüne. İstanbul Üniversitesi Sosyoloji Dergisi, 3(13), ss. 63-69.

Eryılmaz, Ç. (2019). Durkheim'da toplum-çevre etkileşimi: dışlayıcı toplumsal olgulara karşı çevreci potansiyel. Ístanbul Üniversitesi Sosyoloji Dergisi, 39(1), ss. 135-157

Esendemir, Ş. (2016). Türkiye'de yerinde yaşlanma ve mekân gerontolojisinin temel paremetreleri. İstanbul Üniversitesi Sosyoloji Dergisi, 36(2), ss. 411-429.

Fındıkoğlu, Z. F. (1941). Neo pozitivizme göre sosyolojik illiyet. İstanbul Üniversitesi Sosyoloji Dergisi, 2(1), ss. 143-157.

Fındıkoğlu, Z. F. (1960). Karabük'ün teşekkülü ve bazı demografik ve iktisadi meseleler, Sosyoloji Konferanslarl Dergisi, Sayı 1, ss. 1-21.

Fındıkoğlu, Z. F. (1961). “Karabük'de sanayileşmenin iktisadi ve ictimai tesirleri”, Sosyoloji Konferansları Dergisi, Sayı 2, ss. 1-37.

Fındıkoğlu, Z. F. (1963). "Beledi hizmetler ve amme idaresi bakımından Karabük", Sosyoloji Konferansları Dergisi, Sayı 2. 
Gofman, A. (2019). Tradition, morality and solidarity in Durkheim's theory. İstanbul Üniversitesi Sosyoloji Dergisi, 39(1), ss. 25-39.

Gökalp, Z. (1917) İçtimaiyat ve fikriyat, İstanbul Üniversitesi Sosyoloji Dergisi, 1(1), ss. 4-8.

Gökalp, Z. (1917). Millî içtimaiyat: usûl. İstanbul Üniversitesi Sosyoloji Dergisi, 1(1), ss. 22-33.

Göney, S. (2012). Türkiye ve Avrupa Birliği. İstanbul Üniversitesi Sosyoloji Dergisi, 3(17), ss. 8190.

Göney, S. (2012). Anılarda ellili yıllar ve üniversite. İstanbul Üniversitesi Sosyoloji Dergisi, 3(12), ss. 1-15.

Gözaydın, İ, Ökten Gülsoy, N. (2011). Günümüzde Durkheim neden okunmalı? İstanbul Üniversitesi Sosyoloji Dergisi, 3(23), ss. 123-135.

Gözaydın, İ, Ökten Gülsoy, N. (2011). Durkheim sosyolojisinde dinin tarihsel ve güncel olanakları. Istanbul Üniversitesi Sosyoloji Dergisi, 3(21), ss. 1-15.

Güler, S. (2012). Cumhuriyet romanında yeni bir dönem: 1950'li yıllar. İstanbul Üniversitesi Sosyoloji Dergisi, 3(12), ss. 71-80.

Güler, H. (2014). Ağrılı göçmenlerin Fransa'ya tutunma stratejileri. İstanbul Üniversitesi Sosyoloji Dergisi, 3(27), ss. 295-315.

Gülsoy, N. (2013). Cezayir deneyiminin Pierre Bourdieu'nün sosyolojik tahayyülüne etkileri: bilimsel bir habitusun doğuşu. İstanbul Üniversitesi Sosyoloji Dergisi, 3(25), ss. 1-30.

Güney, S, Pekman, C, Kabaş, B. (2014). Sokaklardan “Club”lara: Alman-Türk gençliğinin müzik serüveni. İstanbul Üniversitesi Sosyoloji Dergisi, 3(27), ss. 251-271.

Güven, S. (2015). Türkiye'de sağlık sosyolojisi çalışmaları. İstanbul Üniversitesi Sosyoloji Dergisi, 3(29), ss. 127-164.

Hajjar, R. (2016). ABD nizami silahlı güçlerinin yürüttüğü gayrinizami askerî danışmanlık görevi. Ístanbul Üniversitesi Sosyoloji Dergisi, 3(31), ss. 65-92.

Hacıoğlu, S. (2011). Rusya'da sosyoloji öğretimi. İstanbul Üniversitesi Sosyoloji Dergisi, 3(23), ss. 111-122.

İlyasoğlu, A. (2012). Toplumsalın içinde kurgulanan öznenin kendini dile getirme imkanları olarak yaşam anlatıları ve sözlü tarih. Ístanbul Üniversitesi Sosyoloji Dergisi, 3(16), ss. 67-80.

İlyasoğlu, A. (2012). "Gücün oluştuğu alanlarda kendileri egemenlik altındaki egemenler”: Pierre Bourdieu'nün kavramlarından yola çıkarak Ziya Gökalp'e yeniden bakış denemesi. İstanbul Üniversitesi Sosyoloji Dergisi, 3(10), ss. 59-64.

Kabakc1, E. (2011). Fransa'da sosyolojinin tarihi gelişimi ve Fransız üniversitelerinde bugünkü sosyoloji müfredatı. İstanbul Üniversitesi Sosyoloji Dergisi, 3(23), ss. 43-61.

Kabakc1, E. (2011). Comte Pozitivizminin serencamı (1820-1857): pozitif felsefeden insanlık dinine. İstanbul Üniversitesi Sosyoloji Dergisi, 3(23), ss. 137-164.

Kabakcı, E. (2015). Bir yeniden yorumlama örneği: Ahmed Rıza'nın "Pozitivizm"i. İstanbul Üniversitesi Sosyoloji Dergisi, 3(28), ss. 27-58.

Kaçar, M. (2011). Türkiye'de modernleşmenin öncü kurumları. İstanbul Üniversitesi Sosyoloji Dergisi, 3(19), ss. 127-149.

Kaçmazoğlu, H. B. (2002). Türk sosyoloji tarihi üzerine araştırmalar: öncüleri ve temelleri çerçevesinde yaklaşımlar, Birey Yayıncılık. 
Kaçmazoğlu, H. (2012). Türkiye'de sosyoloji çalışmaları: 1950-1960 dönemi. İstanbul Üniversitesi Sosyoloji Dergisi, 3(4), ss. 131-190.

Kadıoğlu, S. ve Erginöz, G. Ş. (2009). “Gerhard Kessler'in Türk sosyolojisine katkıları”, Türkiye'de toplumbilimlerinin gelişimi I-kıta Avrupası etkisi-içinde, (Ed. Ertan Eğribel ve Ufuk Özcan), Sosyoloji Yı1lığı 18, Kitabevi, ss.438-456.

Kanlıdere, A. (2012). Yusuf Akçura ve Kuzey Türkleri. İstanbul Üniversitesi Sosyoloji Dergisi, $3(18)$, ss. $235-258$.

Karaboğa, K. (2012). Shakespeare'in ütopyasında siyaset ve toplumsal düzen- Firtına'nın düşündürdükleri. İstanbul Üniversitesi Sosyoloji Dergisi, 3(18), ss. 25-42.

Karademir Hazır, İ, Çelik, K, Kalaycıoğlu, S. (2016). Kuşak-içi ve kuşaklararası toplumsal hareketliliğin yörüngesi: Ankara ili örneği. İstanbul Üniversitesi Sosyoloji Dergisi, 36(1), ss. 175-205.

Karahan, Z. (2012). 1991 erken genel seçimleri ve reklam Ajansları'nın etkinlikleri. İstanbul Üniversitesi Sosyoloji Dergisi, 3(4), 225-250.

Karakaya, M. (2016). Son klasik, ilk modern: Pitirim Aleksanroviç Sorokin ve toplumsal hareketlilik. İstanbul Üniversitesi Sosyoloji Dergisi, 36(1), ss. 207-226.

Karakaya, M. (2019). Bütünleşmiş kültürün toplumsal dinamikleri: Sorokin'in uygarlık(lar) okumas1. İstanbul Üniversitesi Sosyoloji Dergisi, 38(2), ss.377-402.

Kardeş, M, Turhan, Ö. (2011). Durkheim'da süreklilik ve kopuş olarak felsefe ve sosyoloji ilişkisi. Istanbul Üniversitesi Sosyoloji Dergisi, 3(21), ss. 187-198.

Kardeş, M. (2015). Aşırı-bireycilik ve otoritarizm ikileminin ötesinde eğitimde otorite sorunu. İstanbul Üniversitesi Sosyoloji Dergisi, 3(30), ss. 39-52.

Kaya, T., Turhan, R. (2012). Ziya Gökalp'in yaşam öyküsü. İstanbul Üniversitesi Sosyoloji Dergisi, 3(13), ss. 1-6.

Kaya, T. (2012). Immanuel Wallerstein: eserleri çerçevesinde entelektüel gelişimi. Ístanbul Üniversitesi Sosyoloji Dergisi, 3(14), ss. 101-118.

Kaya, T. (2015). ABD'de ev okulu uygulamasının tarihsel gelişimi ve bugünkü durumu üzerine bir değerlendirme. İstanbul Üniversitesi Sosyoloji Dergisi, 3(30), ss. 79-98.

Kılıçoğlu, G, Acat, M, Karadağ, E. (2015). İngiltere'deki Türk öğrencilerin kültürleşme tercihleri ve bu tercihlerin okula aidiyet duygusuyla ilişkisi. İstanbul Üniversitesi Sosyoloji Dergisi, 3(30), ss. 195-225.

Kılınç, Ö, Uztuğ, F. (2016). Televizyon dizilerinde yaşl1lığın temsili. İstanbul Üniversitesi Sosyoloji Dergisi, 36(2), ss. 477-506.

Kiren, A. (2017). Nasirüddin Şah Dönemi İranı'nda (1848-1896) modernleşme ve meşruiyet araçlarından biri olarak müzik. İstanbul Üniversitesi Sosyoloji Dergisi, 37(1), ss. 101-118.

Koytak, E. (2013). Tahakküme hükmetmek: Bourdieu sosyolojisinde toplum ve bilim ilişkisi. İstanbul Üniversitesi Sosyoloji Dergisi, 3(25), ss. 85-101.

Kösemihal, N.Ş. (1964). Kürsümüzün 50. y1lı münasebetiyle Ziya Gökalp. İstanbul Üniversitesi Sosyoloji Dergisi, 2(19-20), ss. 260-263.

Kösemihal, N. Ş. (1967). Toplumsal çevre ve konut ilişkileri. İstanbul Üniversitesi Sosyoloji Dergisi, 2(21-22), ss. 175-184. 
Kösemihal, N. Ş. (1967). Sosyolojide yöntem. İstanbul Üniversitesi Sosyoloji Dergisi, 2(21-22), ss. $1-16$

Kösemihal, N. Ş. (1967). Yurdumuzda edebiyat sosyolojisiyle ilgili araştırmalar., İstanbul Üniversitesi Sosyoloji Dergisi, 2(21-22), ss. 185-192

Malczewski, E. (2019). Durkheim and the nation. İstanbul Üniversitesi Sosyoloji Dergisi, 39(1), ss. 41-64.

Meriç, C. (1967). İdeoloji. İstanbul Üniversitesi Sosyoloji Dergisi, 2(21-22), ss. 119-142

Meriç Yazan, Ü. (2012). Türkiye'de kadın ve sosyo-ekonomik analizi. İstanbul Üniversitesi Sosyoloji Dergisi, 3(4), ss. 191-204.

Meriç, Ü. (2012). Rönesans Avrupa'sında sosyal düşünce. İstanbul Üniversitesi Sosyoloji Dergisi, 3(11), ss. 151-171.

Narter, M. (2012). Sosyal Psikoloji'nin sosyal kavramına dair öneriler. İstanbul Üniversitesi Sosyoloji Dergisi, 3(15), ss. 23-30.

Nermi, M. (1964). Ziya Gökalp'le ilgili anılar. İstanbul Üniversitesi Sosyoloji Dergisi, 2(19-20), ss. 271-273.

Nerse, S. (2015). Türkiye kır çalışmalarında paradigma değişimi. Ístanbul Üniversitesi Sosyoloji Dergisi, 3(29), ss. 165-183

Neuman, W. L. (2012). Toplumsal araştırma yöntemleri nitel ve nicel yaklaşımlar I, Çev. Sedef Özge, Yayın Odası.

Nur, A, Koytak, E. (2015). Mümkün Bourdieu'ler uzayında bir Bourdieu: Türkiye bilimsel üretim alanında Bourdieu sosyolojisi. İstanbul Üniversitesi Sosyoloji Dergisi, 3(29), ss. 331-363.

Okan, O. (1989). Sosyologlarımız ve tarihi gerçekler önünde Prens Sabahattin. İstanbul Üniversitesi Sosyoloji Dergisi, 3(1), ss. 97-106.

Okan, O. (2015). Economics, national economics and Ziya Gökalp. İstanbul Üniversitesi Sosyoloji Dergisi, 3(28), ss. 123-137.

Omay, M. (2012). Ütopya üzerine genel bir inceleme. Istanbul Üniversitesi Sosyoloji Dergisi, 3(18), ss. $1-14$.

Özakpınar, Y. (2012). Ziya Gökalp'in batı medeniyetine bakışı. İstanbul Üniversitesi Sosyoloji Dergisi, 3(10), ss. 5-10.

Özatalay, C. (2015). Türkiye'de ekonomi sosyolojisi: bilanço ve perspektifler. İstanbul Üniversitesi Sosyoloji Dergisi, 3(29), ss. 29-82.

Özcan, Z., Çağlar, A., Gültekin, R. (1991). Polis akademisi öğrencilerinin sosyo ekonomik geçmişleri. İstanbul Üniversitesi Sosyoloji Dergisi, 3(2), ss. 221-242.

Özcan, U. (2012). Kadro hareketi üzerine sosyolojik bir deneme. İstanbul Üniversitesi Sosyoloji Dergisi, 3(3), ss. 97-130.

Özcan, U. (2012). Wilson prensipleri üzerine. İstanbul Üniversitesi Sosyoloji Dergisi, 3(4), ss. 3748.

Özcan, U. (2011). 1980 sonrasında Türk sosyolojisinde değişen temalar üzerine bazı gözlemler. Istanbul Üniversitesi Sosyoloji Dergisi, 3(19), ss. 227-236.

Özdemir, Ş. (2012). Karşılaştırmalı bir perspektiften kapitalizm ve kültür. İstanbul Üniversitesi Sosyoloji Dergisi, 3(17), ss. 49-79. 
Özgür, E. (2013). Yaşa göre değer farkl11ıkları ve siyasi kuşak aidiyeti. İstanbul Üniversitesi Sosyoloji Dergisi, 3(26), ss. 45-76.

Özkişi, Z. (2017). Ekspresyonizm ve müzik: 20. yüzyılın ilk yarısında II. Viyana okulu çevresinde gelişen "yeni müzik" yaklaşımı ve müzikal modernizm. İstanbul Üniversitesi Sosyoloji Dergisi, 37(1), ss. 143-156.

Parin, S. (2011). Dilencilik yoksulluk ilişkisi. İstanbul Üniversitesi Sosyoloji Dergisi, 3(20), ss. 23 37.

Park, R. E., Burgess, E. (1941). Sosyolojiye giriş. İstanbul Üniversitesi Sosyoloji Dergisi, 2(1), ss. 170-201.

Park, R., Burgess, E. (1941b). Tecerrüd. İstanbul Üniversitesi Sosyoloji Dergisi, 2(1), ss. 202-217.

Prens Sabahattin (1999), Türkiye nasıl kurtarllabilir? Çev. Fahri Unan, Ayraç Yayınları.

Sadak, N. (1917) İçtimaiyat nedir? İstanbul Üniversitesi Sosyoloji Dergisi, 1(1), ss.15-21.

Sadak, N. (1917). İçtimaiyat bir ilim midir? İstanbul Üniversitesi Sosyoloji Dergisi, 1(2), ss. 94-103.

San, C. (2012). Türkiye'de siyasetin gölgesinde sosyoloji bilimi. İstanbul Üniversitesi Sosyoloji Dergisi, 3(17), ss. 101-113.

San, C. (2011). Toplumbilimsel yöntem açısından Durkheim ve Weber. İstanbul Üniversitesi Sosyoloji Dergisi, 3(21), ss. 17-39.

Saygılıgil, F. (2015). Erken Cumhuriyet Dönemi aydınlarından: Mediha Esenel (Berkes). İstanbul Üniversitesi Sosyoloji Dergisi, 3(28), ss. 223-240.

Segal, D, Segal, M, Reed, B. (2016). Modern ordu teşkilatında çeşitlilik ve vatandaşlık. Ístanbul Üniversitesi Sosyoloji Dergisi, 3(31), ss. 25-44.

Sencer, M. (1964). Sosyoloji Kürsüsü'nün 50. kuruluş y1ldönümünde Ziya Gökalp. İstanbul Üniversitesi Sosyoloji Dergisi, 2(19-20), ss. 280-283.

Sencer, M. (1967). Bir sosyal sınıf kriteri olarak yerleşme kesimi ve konut. İstanbul Üniversitesi Sosyoloji Dergisi, 2(21-22), ss. 199-212.

Sencer, M. (1967). Türkiye'de konut tasarımlarında sosyal sınıf ayrımları yönünden uygulanabilir ilkeler. İstanbul Üniversitesi Sosyoloji Dergisi, 2(21-22), ss. 213-219.

Sencer, M. (1967) Sosyolojik açıdan Türkiye'de ilköğretim. İstanbul Üniversitesi Sosyoloji Dergisi, 2(21-22), ss. 53-101.

Sevinç, A. (2012). Hayal gücüne güç katan toplumsal arka plan: 1960'ların ütopya eskizleri için altlık çalışması. Ístanbul Üniversitesi Sosyoloji Dergisi, 3(18), ss. 173-194.

Sezer, B. (1989). Türk sosyologlar1 ve eserleri I. İstanbul Üniversitesi Sosyoloji Dergisi, 3(1), ss. 196.

Soykan, Ö. (2011). Modernite ve anarşizmle ilgisi bakımından ilerleme kavramının bir çözümlemesi. İstanbul Üniversitesi Sosyoloji Dergisi, 3(19), ss. 37-52.

Sönmez, A. (2019). Durkheim'ın toplumu bir özne, toplumsalı bir nesne olarak kavramsallaştırma çabası. Ístanbul Üniversitesi Sosyoloji Dergisi, 39(1), ss. 159-174.

Sunar, L. (2012). Batı düşüncesinde yeni arayışlar ve Roy Bhaskar'ın eleştirel realizm felsefesi. İstanbul Üniversitesi Sosyoloji Dergisi, 3(15), ss. 85-100. 
Sunar, L. (2012). XIX. yüzyıl Avrupası'nda emperyalizm algısı. İstanbul Üniversitesi Sosyoloji Dergisi, 3(14), ss. 57-80.

Sunar, L. (2015). Türkiye'de sosyal bilimlerde toplumsal değişim. İstanbul Üniversitesi Sosyoloji Dergisi, 3(29), ss. 83-125.

Sunar, L. (2012). Aydınlanma döneminde Doğuya bakış: değişen ilgi ve söylemler. İstanbul Üniversitesi Sosyoloji Dergisi, 3(24), ss. 59-82.

Şahin, M. C. (2017). Türk sosyolojisinin kısa tarihi: dönemler, şahıslar ve ana yönelimler, İslami Ilimler Dergisi, 12(1), 7-41.

Şan, M. (2012). Sosyal bilimleri yeniden kurgulamak: Avrupa-merkezci yaklaşımların aşılması çabaları. Ístanbul Üniversitesi Sosyoloji Dergisi, 3(15), ss. 57-84.

Şatıroğlu, A. (2003). Kent merkezinde yoksullaşan bir bölge Tomtom Mahallesi. İstanbul Üniversitesi Sosyoloji Dergisi, 3(7), ss. 97-122.

Şatıroğlu, A. (2003). Yoksulluk sempozyumu. İstanbul Üniversitesi Sosyoloji Dergisi, 3(7), ss. 201206.

Şatıroğlu, A. (2012). Edebiyat sosyolojisi. İstanbul Üniversitesi Sosyoloji Dergisi, 3(11), ss. 173177.

Şentürk, M. (2012). Türkiye'de yoksulluk çalışmaları. İstanbul Üniversitesi Sosyoloji Dergisi, 3(18), ss. 205-233.

Taftalı, O. (2012). Toplum ve tarih metodolojisi bakımından subjektivizmin bazı ipuçları üzerine. İstanbul Üniversitesi Sosyoloji Dergisi, 3(24), ss. 257-277.

Tanyol, C. (1947). İçtimai monografi hazırlıkları: Prens Sabahaddin. İstanbul Üniversitesi Sosyoloji Dergisi, 2(4-5), ss. 145-175.

Tanyol, C. (1952). Baraklarda örf ve adet araştırmaları 1. İstanbul Üniversitesi Sosyoloji Dergisi, 2(7), ss. 71-108.

Tanyol, C. (1953). Baraklarda örf ve adet araştırmaları 2. İstanbul Üniversitesi Sosyoloji Dergisi, 2(8), ss. 126-135.

Tanyol, C. (1954). Baraklarda örf ve adet araştırmaları 3. Ístanbul Üniversitesi Sosyoloji Dergisi, 2(9), ss. 67-96.

Tanyol, C. (1958). Traktör giren 50 köyde nüfus hareketlerinin ve içtimai değişimlerin kontrolü. Ístanbul Üniversitesi Sosyoloji Dergisi, 2(13-14), ss. 198-218.

Tanyol, C. (1961). Peşke Binamlısı köyü. İstanbul Üniversitesi Sosyoloji Dergisi, 2(16), ss. 17-59.

Tanyol, C. (1962). Elifoğlu köyü. İstanbul Üniversitesi Sosyoloji Dergisi, 2(17-18), ss. 171-222.

Tanyol, C. (1962). Türkiye'de köye yönelme hareketleri. İstanbul Üniversitesi Sosyoloji Dergisi, 2(17-18), ss. 223-241.

Tanyol, C. (1964). Ziya Gökalp'in kişiliği ülkücülüğü bilim adamlığı. İstanbul Üniversitesi Sosyoloji Dergisi, 2(19-20), ss. 264-270.

Taşçığlu, R. (1955). Manisa ili Mütevelli köyü monografisi. İstanbul Üniversitesi Sosyoloji Dergisi, 2(10-11), ss. 28-31.

Taşçığlu, R. (1955). Manisa ili Kayalıoğlu köyü monografisi. İstanbul Üniversitesi Sosyoloji Dergisi, 2(10-11), ss. 32-35. 
Taşkent, A. (2012). -Arnold, Creswell ve Grabar metinleri bağlamında- İslam sanatı ve oryantalist yaklaşımlar üzerine bir inceleme 1. İstanbul Üniversitesi Sosyoloji Dergisi, 3(24), ss. 155181.

Tatlıcan, Ü. ve Balkız, B. (2017). Emile Durkheim'in sosyolojisi ve felsefi düşüncesi, Çev. Ümit Tatlican, Islık Yayınları.

Topgül, S. (2016). Çalışma yaşamında yaşlı ayrımcılı̆̆ı mı yaş ayrımcılığı mı? İstanbul Üniversitesi Sosyoloji Dergisi, 36(2), ss. 373-391.

Tuna, K. (2003). Küresel mi/yerel mi: neler oluyor bize? İstanbul Üniversitesi Sosyoloji Dergisi, $3(6)$, ss. 1-12.

Turan, S, Armağan, Y, Çakmak, E. (2015). Türk eğitim sisteminde okullar ve dershaneler: çoklu paradigma açısından bir inceleme. Ístanbul Üniversitesi Sosyoloji Dergisi, 3(30), ss. 275295.

Turhan, M. (1957). Köy tetkiklerinde kullanılacak metotlar hakkında bazı düşünceler. İstanbul Üniversitesi Sosyoloji Dergisi, 2(12), ss. 98-103.

Turhan, R. (2012). Yeni partiler ve Demokrat Parti’nin seçim başarısı. İstanbul Üniversitesi Sosyoloji Dergisi, 3(12), ss. 41-47.

Turhan, R. (2015). Türkiye'de Cumhuriyetin erken döneminde Max Weber etkisi ve bu etkiyi anlamak. Ístanbul Üniversitesi Sosyoloji Dergisi, 3(29), ss. 259-291.

Turner, S. (2012). Londra'da yaşayan Türklerin integrasyonu ve İngilizlerle evlilikleri. Ístanbul Üniversitesi Sosyoloji Dergisi, 3(4), ss. 205-224.

Tüfekçioğlu, H. (2012). Cumhuriyet ideolojisi ve Türk basını. İstanbul Üniversitesi Sosyoloji Dergisi, 3(3), ss. 45-96.

Tümertekin, E. (1961). İstanbul'da sanayi faaliyetlerinin bünyesi ve Türkiye sanayiindeki yeri. İstanbul Üniversitesi Sosyoloji Dergisi, 2(16), ss. 105-125.

Türkdoğan, O. (2012). Gökalp sosyolojisinde aydın sınıfın yapısı. İstanbul Üniversitesi Sosyoloji Dergisi, 3(10), ss. 29-38.

Tütengil, C. O. (1955). Keçiller köyü incelemesi. İstanbul Üniversitesi Sosyoloji Dergisi, 2(10-11), ss. $36-43$.

Tütengil, C. (1964). İstanbul Üniversitesi sosyoloji öğretimi ve Ziya Gökalp. İstanbul Üniversitesi Sosyoloji Dergisi, 2(19-20), ss. 274-279.

Üçer, M. (2016). Sınıflar ve duyguları: tabakalaşma çalışmalarında duygulara yer açmak. Ístanbul Üniversitesi Sosyoloji Dergisi, 36(1), ss. 227-247.

Ülken, H. Z. (1941). Sosyolojinin mevzuu ve usulü. İstanbul Üniversitesi Sosyoloji Dergisi, 2(1), ss. 3-142.

Ülken, H. Z. (1998). İslam felsefesi kaynakları ve etkileri: eski Yunandan çă̆daş düşünceye doğru, Ülken Yayınları.

Ülken, H. Z. (2004). Türk tefekkürü tarihi, Yapı Kredi Yayınları.

Ülken, H. Z. (2005). Türkiye'de çağdaş düşünce tarihi, Ülken Yayınları.

Ülken, H. Z., Tanyeli, A. (1955). Gönen bölge monografisi. İstanbul Üniversitesi Sosyoloji Dergisi, 2(10-11), ss. 115-154.

Yalman, A. E. (1917). İçtimaiyatta ihsai usul. İstanbul Üniversitesi Sosyoloji Dergisi, 1(1), ss. 9-14. 
Yaman, Ö, Akyurt, M. (2013). Sosyal hizmete kültürel yaklaşım: 2011 Van depremi örneği. Ístanbul Üniversitesi Sosyoloji Dergisi, 3(26), ss. 105-144.

Yetim, Y, Çağlayandereli, M. (2012). Toplumsal algı boyutuyla sokakta çalışan çocuklar: Mersin örneği. Ístanbul Üniversitesi Sosyoloji Dergisi, 3(14), ss. 31-55.

Yetim, N. (2012). İş ve örgüt yazınında oryantalist eğilimler ve “diğeri”nin yüzü. İstanbul Üniversitesi Sosyoloji Dergisi, 3(24), ss. 209-232.

Yıldırım, A., Şimşek, H. (2005). Sosyal bilimlerde nitel araştırma yöntemleri. Seçkin Yayıncılık.

Yılmaz Şener, M. (2016). Kadınlar altın yaka takabilir mi? Türkiye'de eğitimli kadınlar için iş hayatı. İstanbul Üniversitesi Sosyoloji Dergisi, 36(1), ss. 13-40.

Yörükan, T. Cebe, T. (1955). Çatak köyü araştırması. İstanbul Üniversitesi Sosyoloji Dergisi, 2(1011), ss. 1-27. 